\title{
CO MARYJA MA DO POWIEDZENIA MUZUŁMANOM? - MOŻLIWOŚĆ RECEPCJI MARYJNEGO ORĘDZIA
}

\section{DWIE PERSPEKTYWY PODJETEGO TEMATU}

Gdyby pozostać jedynie na pierwszej części zaproponowanego powyżej tematu, należałoby odpowiedzieć w bardzo prosty sposób Maryja wszystkim (a więc i muzułmanom) ma do powiedzenia to samo, wskazuje na Jezusa i mówi: „Zróbcie wszystko, cokolwiek wam powie" $(\mathrm{J} 2,5)$. W tym przecież spełnia się misja Maryi - to Ta, która dała nam Chrystusa i która, jak pięknie ukazuje to ikonografia, jest Hodegetrią wskazującą Drogę, Prawdę i Życie (cf. J 14, 6) - czyli Jezusa. Maryja zatem nie ma jakiegoś specjalnego orędzia dla muzułmanów, bo nie ma Ona nic lepszego do dania komukolwiek, jak swojego Syna. Dlatego prawdziwa mariologia jest zawsze chrystocentryczna, prowadzi do Chrystusa i łączy z Nim¹. Maryja obecna

1 Trafnie ujął zależność mariologii od chrystologii ks. Roman E. Rogowski: „(...) jakakolwiek próba oddzielenia mariologii od chrystologii jest nieporozumieniem, a tym bardziej próba jakiegokolwiek izolowania przywilejów maryjnych (...), od Osoby Chrystusa i Jego zbawczego dzieła jest błędem i stanowi pewnego rodzaju «krzywdę» wyrządzoną samej Maryi”. R.E. Rogowski, Chrystologiczny sens niepokalanego poczęcia Maryi, w: J. Kumala (red.), Tota pulchra es Maria, Licheń 2004, 177. 


\section{WHAT IS OUR LADY'S MESSAGE TO MUSLIMS? - THE RECEPTION OF THE MARY'S ADDRESS}

\section{TWO APPROACHES}

Should we focus only on the first part of the title, the answer would be very simple: Mary tells the same thing to all (and so to Muslims), pointing to Jesus and saying: „Do whatever he tells you”. (Jn 2:5) This is where Maryam's mission is fulfilled - she is the one who gave us Christ and who, as iconography beautifully shows, is Hodegetria indicating the Way, the Truth and the Life (cf. Jn 14:6) that is Jesus. Mary, therefore, has no special message for Muslims, for she has nothing better to give to people than her Son. That is why true Mariology is always Christocentric, leads to Christ and connects with Him. ${ }^{1}$. Mary, present in the community of the Church in a special way $^{2}$, is the first to fulfil the missionary mandate of

${ }^{1}$ Roman E. Rogowski correctly captures the dependence of Mariology on Christology: „(...) any attempt to separate Mariology from Christology is a misunderstanding, let alone an attempt to isolate Marian privileges in any way (...) from the Person of Christ and His salvific work is a mistake and represents a kind of „harm” done to Mary herself. Rogowski, R.E. Chrystological Significance of the Immaculate Conception of Mary, in: Kumala, J. (ed.), (2004) Tota pulchra es Maria, Licheń, 177.

2 This was clearly indicated by the last Council. Cf. II Vatican Council, Dogmatic Constitution on the Church, 52-69 (hereinafter: DCC). 
118 KS. PIOTR KACZMAREK • CO MARYJA MA DO POWIEDZENIA MUZUŁMANOM...

w szczególny sposób we wspólnocie Kościoła ${ }^{2}$, jako pierwsza wypełnia misyjny nakaz swojego Syna, który po zmartwychwstaniu posłał swoich uczniów: „Idźcie na cały świat i głoście Ewangelię wszelkiemu stworzeniu!" (Mk 16, 15). Przesłanie Maryi jest uniwersalne, bo takie jest orędzie samego Jezusa Chrystusa. Jak przypomniał ks. W. Chrostowski: „Jezus Chrystus jest jedyną drogą zbawienia nie tylko chrześcijan, lecz całej ludzkości. Jego męka, śmierć i zmartwychwstanie mają wartość uniwersalną i nie wykluczają nikogo"3.

$\mathrm{Z}$ drugiej strony mądra matka wie, że dziecko trzeba przeprowadzić przez kolejne etapy rozwoju, iż niczego nie wolno przyśpieszać. Nie oczekuje się od noworodka, że od razu będzie chodzić, albo od kilkulatka, iż w jednej chwili zrozumie skomplikowane działania matematyczne. Człowiek wpisany w czas podlega prawu rozwoju. Podobnie jest $\mathrm{z}$ wiarą, człowiek musi w niej dojrzewać, odkrywając powoli coraz głębsze pokłady Bożej miłości i mnogość zadań, które Bóg przed człowiekiem stawia. Stąd druga część tematu niniejszego szkicu. Pytamy, jaka jest możliwość recepcji maryjnego orędzia przez muzułmanów. To znaczy, chcę ustalić, jakie prawdy religii katolickiej są obecne w muzułmańskim credo. Wydaje się, że tą drogą poszedł II Sobór Watykański w swojej deklaracji Nostra aetate 4 . Ojcowie soborowi wskazali w tym dokumencie punkty wspólne obu religii ${ }^{5}$. Zdajemy sobie jednak sprawę, że jest to tylko pewien etap na drodze do pełnego dialogu. Patrząc bowiem z perspektywy katolickiej, wyznawanie przez muzułmanów monoteizmu (Jednego Boga, który jest litościwy i miłosierny), uznanie Abrahama za wspólnego przodka, szacunek dla Jezusa jako proroka i Maryi (jako matki proroka) oraz

\footnotetext{
2 Wskazał na to dobitnie ostatni sobór. Cf. II Sobór Watykański, Konstytucja dogmatyczna o Kościele, 52-69 (dalej: KK).

${ }_{3}$ Prawda, Chrystus, Judaizm. Z księdzem profesorem Waldemarem Chrostowskim rozmawiają: Grzegorz Górny i Rafat Tichy, Warszawa 2018, 262.

${ }^{4}$ Cf. II Sobór Watykański, Deklaracja o stosunku Kościoła do religii niechrześcijańskich, 3 .

5 Szczegółowo to zagadnienie zostało omówione w: P. Kaczmarek, ,S Stowa-klucze” $w$ dialogu Kościoła Rzymsko-katolickiego z islamem po Soborze Watykańskim II, „Warszawskie Studia Teologiczne” 25(2012)1, 239-252.
} 
her Son, who after the Resurrection sent his disciples: „Go into the whole world, and preach the Gospel to all creation!" (Mark 16:15). Maryam's message is universal, because that is the message of Jesus Christ himself. As Fr. Chrostowski reminded us ,Jesus Christ is the only way of salvation not only for Christians, but for all humanity. His Passion, death and resurrection have universal value and do not exclude anyone"s.

On the other hand, a wise mother knows that the child must be guided through successive stages of development, that nothing must be accelerated. A newborn is not expected to walk at once, or a several-year-old to understand complicated mathematical formulas in an instant. A person who is inscribed in time is subject to the law of development. The same is true of faith, man must mature in it, slowly discovering ever deeper layers of God's love and the multitude of tasks that God sets before man. Hence the second part of the title of this paper. We ask what is the possibility of the reception of the Mary's message by Muslims. In other words, the author seeks to establish what truths of the Catholic religion are present in the Muslim creed. It seems that this was the path taken by the Second Vatican Council in its declaration Nostra aetate ${ }^{4}$. The Council fathers identified common points between the two religions in this document ${ }^{5}$. We realise, however, that this is only a certain stage on the road to full dialogue. From a Catholic perspective, the Muslims' confession of monotheism (the One God who is compassionate and merciful), the recognition of Abraham as a common ancestor, respect for Jesus as a prophet and Maryam (as the mother of the prophet) and the acceptance of certain ascetic and devout practices is not yet a condition of salvation. As Dominus Iesus declaration clearly stresses: ,It is to be firmly believed

\footnotetext{
${ }^{3}$ Prawda, Chrystus, Judaizm. Z księdzem profesorem Waldemarem Chrostowskim rozmawiają: Grzegorz Górny i Rafat Tichy, Warsaw 2018, 262.

${ }^{4}$ Cf. II Vatican Council, Declaration on the Relation of the Church to Non-Christian Religions, 3.

5 This issue is discussed in detail in: Kaczmarek, P. ,Stowa-klucze” $w$ dialogu Kościoła Rzymsko-katolickiego z islamem po Soborze Watykańskim II, „Warszawskie Studia Teologiczne" 25(2012)1, 239-252.
} 
120 KS. PIOTR KACZMAREK • CO MARYJA MA DO POWIEDZENIA MUZUŁMANOM...

przyjmowanie pewnych praktyk ascetyczno pobożnościowych, nie jest jeszcze warunkiem zbawienia. Jak dobitnie podkreśliła deklaracja Dominus Iesus: „Należy mianowicie mocno wierzyć w to, że w tajemnicy Jezusa Chrystusa, wcielonego Syna Bożego, który jest «drogą, prawdą i życiem» (J 14, 5), zawarte jest objawienie pełni Bożej prawdy"6.

Chcąc podjąć próbę określenia granic recepcji maryjnego orędzia przez muzułmanów, należy najpierw omówić, jak postrzegają Maryję wyznawcy islamu, co o Matce Jezusa mówi Koran i sunna (Tradycja muzułmańska) - czyli co z chrześcijańskiego obrazu Maryi islam przyjmuje, a co odrzuca. Po drugie, warto przywołać różne próby wzajemnego zrozumienia, które podejmował Kościół w dialogu z islamem. Posłuży to temu, by wskazać na pewne wymiary orędzia maryjnego, które są bliskie muzułmanom. Tak rozpisana problematyka może pomóc w wypracowaniu mariologicznego języka dialogu Kościoła rzymskokatolickiego z islamem.

\section{CO O MARII MÓWI TEOLOGIA MUZULMAŃSKA?}

W Nowym Testamencie występuje kilka kobiet o imieniu Maria, natomiast Koran mówi tylko o jednej Marii, matce Jezusa - jest to zresztą jedyna kobieta wymieniona z imienia w świętej księdze islamu ${ }^{8}$. Co warto dodać, w narracji koranicznej Maria pojawia się jedynie w kontekście osoby Jezusa. To bardzo ważne skojarzenie, albowiem jak w islamie rozumiany jest Jezus, tak też wyjaśniana będzie

${ }^{6}$ Kongregacja Nauki Wiary, Deklaracja ojedyności i powszechności zbawczej Jezusa Chrystusa i Kościoła, Watykan 6.08.2000, nr 5. W dokumencie odnotowano także: „(...) byłoby sprzeczne z wiarą katolicką postrzeganie Kościoła jako jednej z dróg zbawienia istniejącej obok innych, to znaczy równoległe do innych religii, które miałyby uzupełnić Kościół, a nawet mieć zasadniczo taką samą jak on wartość, zmierzając co prawda tak jak on ku eschatologicznemu Królestwu Bożemu". Ibidem, 21.

7 W odniesieniu do stanowiska chrześcijańskiego stosuję imię Maryja, omawiając doktrynę muzułmańską, będę używać imienia Maria.

8 Święta księga muzułmanów wymienia imię Marii 34 razy. 
that in the mystery of Jesus Christ, the incarnate Son of God, who is ,the way, the truth and the life'. (Jn 14:5), there is a revelation of the fullness of God's truth".

In an attempt to define the boundaries of the reception of the Mary's message by Muslims, it is first necessary to discuss how Muslims perceive Mary, what the Quran and Sunnah (Muslim tradition) say about the Mother of Jesus - that is, what Islam accepts and rejects from the Christian image of Maryam. Secondly, it is worth recalling the various attempts at mutual understanding that the Church made in dialogue with Islam. This will indicate certain dimensions of the Mary's message that are close to the Muslims. Issues dealt with in this way may help to develop the Mariological language of dialogue between the Roman Catholic Church and Islam.

\section{WHAT DOES MUSLIM THEOLOGY SAY ABOUT MARYAM?}

There are several women named Maryam in the New Testament ${ }^{7}$, while the Quran speaks of only one Maryam, the mother of Jesus she is, in fact, the only woman mentioned by name in the Holy Book of Islam ${ }^{8}$. It is worth adding that in the Quranic narrative, Maryam appears only in the context of the person of Jesus. This is a very important association, because as Jesus is understood in Islam, so is the explanation of Maryam's role. As we know, Muslims do not accept the deity of Jesus, considering him only as a great prophet.

${ }^{6}$ Congregation for the Doctrine of the Faith, Declaration on the uniqueness and universality of salvation of Jesus Christ and the Church, Vatican 6.08.2000, no. 5 . The document also notes: „,...) it would be contrary to the faith to consider the Church as one way of salvation alongside those constituted by the other religions, seen as complementary to the Church or substantially equivalent to her, even if these are said to be converging with the Church toward the eschatological kingdom of God." Ibidem, 21

7 With regard to the Christian position, the auther uses the name Mary; when discussing Muslim doctrine, he uses the name Maryam.

8 The Holy Book of Muslims mentions the name of Mary(am) 34 times. 
rola Marii. Jak wiadomo, muzułmanie nie przyjmują Bóstwa Jezusa, uznając Go jedynie za wielkiego proroka. Dlatego też Maria pozostaje jedynie matką proroka. Zwrócił na to uwagę Jan Paweł II w wywiadzie z V. Messorim: „Islam nie jest religią odkupienia. Nie ma w nim miejsca dla krzyża i zmartwychwstania, chociaż wspomniany jest Jezus, ale jedynie jako prorok przygotowujący na przyjście ostatecznego proroka Mahometa. Wspomniana jest Maryja, Jego dziewicza Matka. Ale tylko tyle. Nie ma całego dramatu odkupienia"9.

Maria jest zaliczana przez wyznawców religii muzułmańskiej do czterech wielkich kobiet islamu, obok Fatimy - córki Muhammada, Asji - żony faraona i Chadidży - pierwszej żony Proroka. Jej imię oznacza ,tę, która oddaje cześć Bogu”. Osoba Marii w przekazie koranicznym nie jest jednoznaczna, stanowi połączenie Maryi z Ewangelii i Miriam, siostry Aarona przedstawionej w Starym Testamencie $^{10}$. Trzeba jednak powiedzieć, że choć Muhammad myli te dwie postaci ${ }^{11}$, to jednak w zasadniczym przesłaniu Maria jest przedstawiana jako matka Jezusa, a jej rola jest wyjątkowa. Koran wspomina pięć obrazów związanych z Marią: Jej narodziny, pobyt w świątyni jerozolimskiej, Zwiastowanie, Narodziny Jezusa, a także apologię Jej cnoty czystości i dziewictwa. Część z tych scen odnajdziemy w Ewangeliach (Zwiastowanie, Narodzenie Jezusa i prawdę o dziewictwie Maryi), natomiast wydarzenia dotyczące narodzin i dzieciństwa Marii zostały zapewne zaczerpnięte z pism apokryficznych, które nie pozostały bez wpływu również na Tradycję Kościoła ${ }^{12}$. Jeszcze inne wątki, jak choćby ucieczka do Egiptu, dopisała Tradycja muzułmańska. Jak wyjaśnia E. Sakowicz: „Temat ten pojawił się jednak w licznych legendach muzułmańskich, według których uszła

\footnotetext{
9 Przekroczyć próg nadziei. Jan Pawet II odpowiada na pytania Vittoria Messoriego, Lublin 1994, 82-83.

${ }^{10}$ Cf. M.M. Dziekan, Symbolika arabsko-muzutmańska. Mały słownik, Warszawa 1997, 62.

${ }^{11}$ Czytamy w Koranie: „Oni powiedzieli: «O Mario! Uczyniłaś rzecz niesłychaną! O siostro Aarona»" (19, 27-28 - Koran, tłum. J. Bielawski, Warszawa 1986).

${ }_{12}$ O pobycie Maryi w świątyni, a także Jej rodzicach Joachimie i Annie mówi między innymi Protoewangelia Jakuba.
} 
Therefore, Maryam remains only the mother of the prophet. This was pointed out by John Paul II in an interview with Messori: ,Islam is not a religion of redemption. There is no room for the Cross and the Resurrection. Jesus is mentioned, but only as a prophet who prepares for the last prophet, Muhammad. There is also mention of Mary, His Virgin Mother, but the tragedy of redemption is completely absent."

Mary is one of the four great women of Islam, alongside Fatima, the daughter of Muhammad, Asia, the wife of Pharaoh, and Khadidja, the first wife of the Prophet. Her name means, she who worships God'. The person of Maryam in the Quranic message is not unambiguous, it is a combination of Maryam of the Gospel and Miriam, Sister Aaron presented in the Old Testament. ${ }^{10}$ However, it needs to be said that, although Muhammad confuses these two figures, the essential message is that Maryam is presented as the mother of Jesus, and her role is unique. The Quran mentions five images related to Maryam: Her birth, her stay in the Temple of Jerusalem, the Annunciation, the Birth of Jesus, and the apologia of her virtue of chastity and virginity. Some of these scenes can be found in the Gospels (Annunciation, Birth of Jesus and the truth about Maryam's virginity), while the events concerning Maryam's birth and childhood were probably taken from the apocryphal writings, which also influenced the Tradition of the Church ${ }^{11}$. There are other threads, such as the escape to Egypt, which the Muslim Tradition added. As Sakovich explains: „This subject appeared, however, in numerous Muslim legends, according to which she escaped from ambushes of Roman persecutors lurking for her life. Mary owed her salvation to the miraculous opening of the earth, which absorbed her persecutors". ${ }^{12}$

\footnotetext{
9 Crossing the Threshold of Hope by His Holiness John Paul II. John Paul II answers Vittorio Messori's questions, Alfred A. Knopf (1994), 82-83.

${ }^{10}$ Cf. Dziekan, M.M. (1997) Symbolika arabsko-muzułmańska. Mały słownik, Warsaw, 62.

${ }^{11}$ Mary's stay in the temple, as well as that of her parents Joachim and Anna, is mentioned, among others, by The Protoevangelium of Jacob.

${ }_{12}$ Sakowicz, E. (2002) Doktryna islamu, in: Sakowicz E. (ed.), Czy islam jest religia terrorystów?, Kraków, 76-77.
} 
124 KS. PIOTR KACZMAREK • CO MARYJA MA DO POWIEDZENIA MUZUŁMANOM...

Ona przed zasadzkami rzymskich prześladowców czyhających na jej życie. Ocalenie miała Maryja zawdzięczać cudownemu rozwarciu się ziemi, która pochłonęła jej prześladowców"13.

W Koranie odnajdujemy opis narodzin Marii ${ }^{14}$. Narracja świętej księgi islamu podkreśla Bożą łaskę skierowaną w stronę Marii, nazywanej córką Imrana. Choć jest dziewczynką (a więc jej rola społeczno-religijna w kulturze muzułmańskiej była „z natury” zmarginalizowana), to Bóg przyjmuje to dziecko i obdarza szczególnymi darami. Inny opis również nawiązuje do apokryfów. Mowa o pobycie malutkiej Marii w świątyni jerozolimskiej ${ }^{15}$. Jest ona otaczana w tym świętym miejscu opieką Boga, aniołów, a także kapłanów. Bezpośrednią pieczę pełnił nad nią kapłan Zachariasz, znany nam z Ewangelii mąż św. Elżbiety. W Koranie znajdziemy również scenę Zwiastowania, która jest przywoływana dwukrotnie ${ }^{16}$.

Przekaz koraniczny dość wiernie podąża za narracją zaczerpniętą z Ewangelii wg św. Łukasza, choć różni się w kilku punktach. Tak jak mówi Ewangelia, tak samo w Koranie, wiadomość o narodzinach Mesjasza przekazuje specjalny posłaniec z nieba. Różnica polega na tym, że św. Łukasz wspomina o Archaniele Gabrielu, zaś Koran mówi o aniołach i Duchu, który przyszedł do Marii w postaci młodzieńca. Maria dowiaduje się, że jej syn będzie kimś wyjątkowym, że otrzyma od Boga szczególnie ważną misję do wypełnienia. Zarówno w Ewangelii, jak i w Koranie, Maria zadaje pytanie o sposób realizacji Bożego orędzia, pyta, w jaki sposób stanie się matką, skoro żyje w czystości. Istotna różnica dotyczy natomiast maryjnego „fiat”. Tradycja Kościoła przywiązuje do zgody Maryi wielką wagę. Podkreśla się, że wyraziła

${ }^{13}$ E. Sakowicz, Doktryna islamu, w: E. Sakowicz (red.), Czy islam jest religia terrorystów?, Kraków 2002, 76-77.

${ }^{14}$ Cała scena znajduje się w: Koran 3, 35-37.

15 Można tu wskazać dwa fragmenty: Koran 3, 37; 19, 16-17.

16 Jak zauważa o. G. Bartosik, wydarzenie Zwiastowania było dość ważne dla muzułmanów, dlatego właśnie w Koranie znajdują się dwa opisy tego wydarzenia. Cf. G.M. Bartosik, Maryja w Koranie i w Tradycji muzulmańskiej. Czy osoba Maryi może być pomostem między tymi dwiema wielkimi religiami?, „Studia Theologica Varsaviensia" 45(2007)1, 69. 
In the Quran we find a description of Maryam's birth ${ }^{13}$. The narrative of the Holy Book of Islam highlights God's grace towards Maryam, known as the daughter of Imran. Although she is a girl (so her social and religious role in Muslim culture was marginalized „by nature"), God accepts that child and bestows special gifts. Another description also refers to the apocrypha. Reference is made to the stay of the little Maryam in the temple in Jerusalem ${ }^{14}$. In this holy place, she is protected by God, by angels and also by priests. She was directly cared for by the priest Zachariah, St. Elizabeth's husband, known to us from the Gospel. In the Quran we also find the scene of the Annunciation, which is recalled twice ${ }^{15}$.

The Quranic message quite accurately follows the narrative from St Luke's Gospel, although it differs in several points. Just as the Gospel says, in the Quran, the message of the birth of the Messiah is given by a special messenger from heaven. The difference is that St Luke mentions Archangel Gabriel, while the Quran speaks of angels and the Spirit who came to Maryam as a young man. Mary learns that her son will be someone special, and that he will receive a particularly important mission from God to fulfil. Both in the Gospel and in the Quran, Maryam asks how to carry out God's message, how to become a mother when she lives in chastity. The important difference is in Mary's ,fiat”. The tradition of the Church attaches great importance to Mary's consent. It is emphasized that she gave her consent freely, entrusting her entire future to God. Thanks to Mary's consent, the miracle of the Incarnation of the Son of God could take place. ${ }^{16}$ Muslim perspective is slightly different. The ideal

13 The whole scene is contained in: The Quran 3, 35-37.

14 Two passages can be mentioned here: The Quran 3, 37; 19, 16-17.

15 As Father Bartosik notes, the Annunciation was quite important for Muslims, which is why there are two descriptions of that event in the Quran. Cf. Bartosik, G.M. Maryja w Koranie i w Tradycji muzulmańskiej. Czy osoba Maryi może być pomostem między tymi dwiema wielkimi religiami?, „Studia Theologica Varsaviensia" 45(2007)1, 69.

16 The Second Vatican Council teaches: „The Father of mercies willed that the Incarnation should be preceded by assent on the part of the predestined mother 
126 KS. PIOTR KACZMAREK • CO MARYJA MA DO POWIEDZENIA MUZUEMANOM...

Ona swoją zgodę w sposób wolny, całkowicie zawierzając Bogu swoją przyszłość. Dzięki zgodzie Maryi mógł dokonać się cud Wcielenia Syna Bożego ${ }^{17}$. Optyka muzułmańska jest nieco inna. Ideałem prawdziwego wyznawcy islamu jest poddanie się woli Boga. Poddanie bezwarunkowe, powiedziałbym „,bez zadawania pytań”. Dlatego też Koran przedstawia scenę zwiastowania, w której Maria po prostu dowiaduje się, jaka jest wola Boża. Wszystko zostało postanowione, niebieski zwiastun nie czeka zatem na Jej odpowiedź. Na różnicę w relacji zawartej w Ewangelii i Koranie wskazuje o. G. Bartosik: „Interesujące, że według Koranu Bóg nie oczekuje na wolną odpowiedź Maryi. Wobec jej pytania o to, jak to ma się dokonać, pada ze strony posłańca Bożego krótkie stwierdzenie «Tak będzie». A więc zwiastowanie i dziewicze poczęcie Jezusa w łonie Maryi ukazywane jest jako wydarzenie postanowione przez Boga, do którego człowiek musi się bezwzględnie podporządkować. Nie podkreśla się, tak jak to jest w chrześcijaństwie, znaczenia fiat wypowiedzianego przez Maryję"18. Z chrześcijańskiego punktu widzenia, Maryja również wyraża swoją zgodę, także poddaje się woli Bożej, ale Jej postawa ma charakter dialogiczny. Bóg rozmawia z Maryją, a nie po prostu obwieszcza nakaz, który bezwzględnie należy wypełnić.

W świętej księdze islamu znajduje się także opis narodzin Syna Marii. Jednak od razu należy zauważyć, że narracja koraniczna zupełnie odbiega od ewangelicznego przekazu. Opis zawarty w Koranie

17 II Sobór Watykański naucza: „Było zaś wolą Ojca miłosierdzia, aby Wcielenie poprzedziła zgoda Tej, która przeznaczona została na matkę (...)”. KK, 56. Warto przytoczyć także słowa Jana Pawła II: „I Maryja wyraża tę zgodę, po wysłuchaniu wszystkich słów zwiastuna. Mówi: «Oto ja służebnica Pańska, niech mi się stanie według twego słowa!» (Łk 1, 38). Oto Maryjne fiat - «niech mi się stanie» - zdecydowało od strony ludzkiej o spełnieniu się Bożej tajemnicy. Zachodzi pełna zbieżność ze słowami Syna, który według Listu do Hebrajczyków mówi do Ojca, przychodząc na świat: «Ofiary ani daru nie chciałeś aleś mi utworzył ciało (...) Oto idę (...), abym spełniał wolę Twoją, Boże» $(10,5.7)$. Tajemnica Wcielenia urzeczywistniła się wówczas, gdy Maryja wypowiedziała swoje fiat: «niech mi się stanie według twego słowa!», czyniąc możliwym - na ile wedle planu Bożego od Niej to zależało - spełnienie woli Syna”. Jan Paweł II, Redemptoris Mater, 13.

${ }^{18}$ G.M. Bartosik, art. cit., 71. 
of a true follower of Islam is to submit to the will of God. Surrender unconditionally, I would say, without asking questions'. That is why the Quran presents the scene of the Annunciation, in which Maryam simply finds out what God's will is. Everything is decided, so the blue herald does not await her answer. The difference in the account contained in the Gospel and the Quran is indicated by Fr Bartosik: „It is interesting that according to the Quran, God does not wait for Mary's free answer. Upon her question of how this is to be done, the messenger of God says briefly, „So it will be”. Accordingly, the annunciation and virginal conception of Jesus in Mary's womb is presented as a God-given act, to which man must absolutely abide. The meaning of the fiat spoken by Mary is not emphasised, as is the case in Christianity'. ${ }^{17}$ From a Christian point of view, Mary also gives her consent, she also surrenders to God's will, but her attitude is one of dialogue. God talks to Maryam and does not simply proclaim an injunction, which must absolutely be fulfilled.

The Holy Book of Islam also describes the birth of the Son of Maryam. However, it should be noted immediately that the Quranic narrative differs completely from the evangelical message. The description contained in the Quran coincides rather with what Genesis reports (cf. Genesis 21, 14-19), where it presents the fate of Hagar and her son Ishmael. The Muslims believe that it was Ishmael, not Isaac, who turned out to be the son of the promise God made to Abraham, so

(...)”. CCC, 56. The words of John Paul II are also worth quoting: „Behold, I am the handmaid of the Lord; let it be to me according to your word" (Lk. 1:38). This fiat of Mary-"let it be to me"-was decisive, on the human level, for the accomplishment of the divine mystery. There is a complete harmony with the words of the Son, who, according to the Letter to the Hebrews, says to the Father as he comes into the world: „Sacrifices and offering you have not desired, but a body you have prepared for me.... Lo, I have come to do your will, O God" (Heb. 10:5-7). The mystery of the Incarnation was accomplished when Mary uttered her fiat: „Let it be to me according to your word," which made possible, as far as it depended upon her in the divine plan, the granting of her Son's desire." John Paul II, Redemptoris Mater, 13.

17 Bartosik, G.M. art. cit., 71. 
128 KS. PIOTR KACZMAREK • CO MARYJA MA DO POWIEDZENIA MUZUŁMANOM...

zbiega się raczej z tym, co relacjonuje Księga Rodzaju (cf. Rdz 21, 14-19), gdy prezentuje losy Hagar i jej syna Izmaela. Według muzułmanów, to Izmael, a nie Izaak, okazał się synem obietnicy złożonej Abrahamowi przez Boga, dlatego może tak bardzo scena z synem Hagar została wyróżniona ${ }^{19}$. Podążając za dziewiętnastą surą Koranu (cf. 19, 22-26) dowiadujemy się o Marii, która będąc brzemienną, oddaliła się na pustynię. Tam tracąc siły, prosiła o śmierć. Wtedy Bóg pomógł jej dostrzec źródło wody oraz palmę ze świeżymi daktylami, którymi mogła się posilić.

W Koranie znajduje się jeszcze jedna scena dotycząca Marii; chodzi o fragment mówiący o obronie Jej przed zarzutem o cudzołóstwo. Scena ta nosi znamiona cudowności. Oto w obronie swojej matki przemawia Jezus jako małe dziecko. Jest to obrazowanie dość charakterystyczne dla literatury apokryficznej, z której, jak się wydaje, autor Koranu obficie korzystał.

Chcąc zebrać główne motywy maryjne w Koranie, można wskazać dwa podstawowe rysy teologiczne. Po pierwsze, Maria jest ukazana jako znak dla świata (szczególnie wybranie Marii, oczyszczenie, macierzyństwo i wyjątkowa godność), a po drugie, staje się wzorem dla wierzących (Maria jest wzorem wiary, pobożności, wstrzemięźliwości, ukazywana jest również jako prawdziwa „muzułmanka”) ${ }^{20}$. Wiele z powyższych wymiarów życia Marii może być przyjęte przez wyznawców obu religii. Sprawą rozstrzygającą będzie zawsze osoba Jezusa Chrystusa. Islam bowiem będzie oddawać wielki szacunek Marii, uzna Jej dziewictwo i podkreśli niezwykłe cnoty, ale zawsze będzie widzieć w niej matkę jedynie człowieka. Jest to macierzyństwo

19 Spór o supremację wywołany między Izaakiem a Izmaelem przeniósł się w jakiś sposób na wzajemne relacje islamu i chrześcijaństwa. Obie religie bowiem odczytują rolę dwóch synów Abrahama w odmienny sposób. Poświęciłem temu zagadnieniu osobny szkic: P. Kaczmarek, Poróżnione dzieci Abrahama-kilka myśli na temat dialogu Kościoła katolickiego z islamem, „Studia Loviciensia” 19(2017), 125-137.

${ }^{20}$ Wyróżnienie to podaje za G. Gharibem G.M. Bartosik. Cf. G.M. Bartosik, art. cit., 74-81. Tam również znajduje się rozwinięcie poszczególnych aspektów maryjnego ujęcia w Koranie wraz z odpowiednimi odniesieniami do Biblii. 
probably the scene with the son of Hagar received so much attention ${ }^{18}$. Following the nineteenth Surah of the Quran (cf. 19:22-26), we learn about Maryam, who, being pregnant, went into the desert. There, losing her strength, she asked to die. Then God helped her to see the spring of water and a palm tree with fresh dates that she could eat.

There is another scene in the Quran about Maryam; it is the part about defending her from the charge of adultery. This scene bears the signs of miracles. Here, in defence of his mother, Jesus speaks as a small child. This is an image quite characteristic of apocryphal literature, from which the author of the Quran seems to have profusely availed himself of.

To collect the main Marian motifs in the Quran, two basic theological features can be identified. Firstly, Maryam is shown as a sign to the world (especially Maryam's election, purification, motherhood and exceptional dignity), and secondly, she becomes a role model for believers (Maryam is a role model of faith, piety, temperance, she is also shown as a true „Muslim”) $)^{19}$. Many of these dimensions of Mary's life can be accepted by followers of both religions. The person of Jesus Christ will always be the decisive factor. For Islam will pay great respect to Maryam, recognise her virginity and emphasise her extraordinary virtues, but will always see her as a mother only human. It is an earthly motherhood, although the circumstances surrounding it are filled with miraculous events. Christianity, on the other hand, will emphasise Mary's dignity as

18 The dispute over supremacy between Isaac and Ishmael shifted in some way to the relationship between Islam and Christianity. For the two religions interpret the role of the two sons of Abraham in a different way. Tha author of this paper devoted a separate study to this issue: Kaczmarek, P. Poróżnione dzieci Abrahamakilka myśli na temat dialogu Kościoła katolickiego z islamem, „Studia Loviciensia” 19(2017), 125-137.

19 After Gharib G., Bartosik G.M. provides this distinction Cf. Bartosik G.M., art. cit., 74-81. There is also an elaboration of the various aspects of the Marian treatment in the Quran with appropriate references to the Bible. 
130 KS. PIOTR KACZMAREK • CO MARYJA MA DO POWIEDZENIA MUZUŁMANOM...

ziemskie, choć okoliczności mu towarzyszące są wypełnione cudownymi wydarzeniami. Chrześcijaństwo natomiast będzie podkreślać godność Maryi jako Matki Boga - Theotókos ${ }^{21}$. Oto ramy poza, które nie może wyjść wyznawca islamu.

\section{KOŚCIÓŁ W DIALOGU Z ISLAMEM}

Przeglądając teksty II Soboru Watykańskiego czy późniejszych wypowiedzi Jana Pawła II i Benedykta XVI, próżno szukać wyraźnego rysu mariologicznego w dialogu międzyreligijnym. Osoba Maryi jest przywoływana marginalnie, co nie znaczy jednak, że jest pomijana. Można powiedzieć, że postać Matki Chrystusa jest przywoływana pośrednio. Sobór i papieże mówili bardziej o Jej cnotach i wartościach, którymi żyła, niż o Jej tytule Matki Boga. Rozważę pokrótce, jakim językiem jest budowany dialog między Kościołem a islamem, jakie pojęcia i treści się przywołuje.

II Sobór Watykański zabrał głos na temat dialogu Kościoła z religią muzułmańską. Odwołując się do ogólnej zasady wpisania doświadczenia innych religii w dzieło zbawcze Jezusa Chrystusa i Jego Kościoła ${ }^{22}$, podał jednocześnie szczegółowe wskazania w deklaracji Nostra aetate odnoszące się do wyznawców islamu. Początkowo dokument ten miał być poświęcony głównie religii judaistycznej. Jednak protest środowisk muzułmańskich sprawił, że redakcję deklaracji przesunięto na końcową fazę Soboru, decydując się na doda-

${ }^{21}$ Kwestia dotycząca sporu o tytuł „Matka Boga” została ostatecznie rozwiązana na Soborze w Efezie (431 r.). Ojcowie soborowi podkreślili przede wszystkim dogmat o jedności hipostatycznej Chrystusa, a w konsekwencji także dogmat o Bożym macierzyństwie Maryi. Cf. L. Melotti, Maryja, Matka żyjących. Zarys mariologii, tłum. T. Siudy, Niepokalanów 1993, 76-82.

${ }^{22}$ Chodzi o koncepcję „kręgów przynależności” do Kościoła (cf. KK, 13-17). W jednym z punktów konstytucji wprost mowa jest o muzułmanach: ,plan zbawienia obejmuje także i tych, którzy uznają Stworzyciela, wśród nich zaś w pierwszym rzędzie muzułmanów; oni bowiem wyznając, iż zachowują wiarę w Abrahama, czczą wraz z nami Boga jedynego i miłosiernego, który sądzić będzie ludzi w dzień ostateczny”. KK, 16. 
Mother of God - Theotókos ${ }^{20}$. This is the framework beyond which an Islamist cannot go.

\section{CHURCH IN DIALOGUE WITH ISLAM}

Looking through the texts of the Second Vatican Council or the subsequent statements of John Paul II and Benedict XVI, there is no clear Mariological trait in interreligious dialogue. The person of Mary is mentioned marginally, which does not mean, however, that it is ignored. One could say that the figure of the Mother of Christ is invoked indirectly. The Council and the Popes spoke more about her virtues and the values she lived by, rather than her title of Mother of God. I will briefly consider what language is used to build dialogue between the Church and Islam, what concepts and content are invoked.

The Second Vatican Council spoke of the Church's dialogue with the Muslim religion. Referring to the general principle of inscribing the experience of other religions in the salvific work of Jesus Christ and His Church ${ }^{21}$, it also provided detailed indications in the Nostra aetate declaration relating to followers of Islam. Initially, this document was to be devoted mainly to the Judaic religion. However, the protest of Muslim circles led to the fact that the drafting of the declaration was postponed to the final stage of the Council, deciding to include an appropriate annotation concerning the followers of

20 The dispute over the title 'God's Mother' was finally resolved at the Council in Ephesus (431). The Council Fathers stressed, first and foremost, the dogma of Christ's hypostatic unity and, consequently, the dogma of Mary's divine motherhood. Cf. Melotti, L. Mary, Mother of the Living. Outline of Mariology, Polish transaltion by Siuda T. ( 1993) Niepokalanów, 76-82.

${ }^{21}$ This is the concept of „circles of belonging” to the Church (cf. DCC, 13-17). One of the points of the Constitution explicitly mentions Muslims: „, the plan of salvation also includes those who acknowledge the Creator. In the first place amongst these there are the Muslims, who, professing to hold the faith of Abraham, along with us adore the one and merciful God, who on the last day will judge mankind." DCC, 16. 
nie stosownej adnotacji dotyczącej wyznawców islamu ${ }^{23}$. W swoim wydźwięku deklaracja posiada charakter pastoralny, nie formułuje żadnych regulacji prawnych, ale podkreśla dobrą wolę Kościoła, który pozostaje otwarty na współpracę i próbę wzajemnego zrozumienia. W ten sposób zostaje podkreślony również uniwersalizm Kościoła, który nie ukazuje siebie jako jednej z wielu dróg do Boga, ale jako drogę jedyną. O uniwersalizmie Kościoła, do którego nawiązuje Nostra aetate, pisze o. B. Przybylski: „Uznając, że wszelkie wartości religijne i moralne, jakie istnieją na świecie, pochodzą od Chrystusa i w Nim osiągają pełnię, Kościół współdziała w ich rozwoju, wierząc, że w ten sposób utoruje ludzkości drogę do przyjęcia Ewangelii i pełni zbawienia. Sam zaś kładzie coraz większy nacisk na apostolstwo przykładu, aby przyjęcie wiary było zawsze aktem w pełni wolnym, niewywołanym żadnym przymusem" ${ }^{24}$.

Ważnym sformułowaniem jest tutaj ,,apostolstwo przykładu”. Kolejni papieże będą bowiem podejmować ten wymiar realizacji dialogu międzyreligijnego. Była to też okazja dla chrześcijan, by dawać świadectwo, o czym przypominały dokumenty Kościoła: „Gdy chodzi o głębszą jeszcze warstwę dialogu, ludzie zakorzenieni we własnych tradycjach religijnych mogą dzielić się ze sobą doświadczeniami modlitwy, kontemplacji, wiary i uczestnictwa, a także w zakresie wyrażania poszukiwań Absolutu i prowadzących ku niemu dróg"25.

Jan Paweł II jako jeden z ojców soborowych, dobrze rozumiał nowy powiew Ducha Świętego. Z jednej strony jego pontyfikat był próbą kontynuacji i wprowadzania dyrektyw oraz postulatów II Soboru Watykańskiego, a z drugiej strony Papież z Polski zaproponował wiele nowych inicjatyw ${ }^{26}$. Już podczas pierwszego spotkania

${ }^{23}$ Cf. I. Krasicki, Watykan na rozdrożu (1960-1970), Warszawa 1971, 230-232.

${ }^{24}$ Cf. B. Przybylski, Kościól a religie niechrześcijańskie, „Ateneum Kapłańskie” 73(1969)9-10, zeszyt 2, nr 364, 292.

${ }_{25}$ Sekretariat dla Niechrześcijan, Postawa Kościoła wobec wyznawców innych religii, nr 35, w: „L'Osservatore Romano” (1984)7, 5.

26 Właśnie w takiej perspektywie podjąłem $\mathrm{w}$ jednym $\mathrm{z}$ artykułów temat wkładu Jana Pawła II w dialog chrześcijańsko-muzułmański. Tam też zamieściłem wiele odnośników do wypowiedzi papieża na temat islamu: cf. P. Kaczmarek, Jan Pawel 
Islam $^{22}$. The declaration takes on a pastoral character, does not formulate any legal regulations, but emphasises the good will of the Church, which remains open to cooperation and an attempt at mutual understanding. In this way, it also emphasises the universalism of the Church, which does not show itself as one of many ways to God, but as the only way. The universalism of the Church, to which Nostra aetate refers, is discussed by Fr. Przybylski: „Recognizing that all the religious and moral values that exist in the world come from Christ and reach their fullness in him, the Church collaborates in their development, believing that in this way it will pave the way for humanity to receive the Gospel and the fullness of salvation. Yet, the Church itself places ever greater emphasis on the apostolate of example, so that the acceptance of faith is always a fully free act, without any compulsion'. ${ }^{23}$

A very important expression here is ,the apostolate of the example'. Successive popes would undertake this dimension of implementing interreligious dialogue. It was also an opportunity for Christians to give testimony, as recalled by Church documents: ,When it comes to an even deeper layer of dialogue, people rooted in their own religious traditions can share their experiences of prayer, contemplation, faith and participation, as well as the search for the Absolute and the paths leading towards it." 24

John Paul II, as one of the Council fathers, understood well the new breath of the Holy Spirit. On the one hand, his pontificate was an attempt to continue and introduce the directives and demands of the Second Vatican Council, and on the other hand, the Polish Pope presented many new initiatives ${ }^{25}$. It was during the first meeting with

${ }^{22}$ Cf. Krasicki I. (1971), Watykan na rozdrożu (1960-1970), Warsaw, 230-232.

${ }^{23}$ Cf. Przybylski B., Kościół a religie niechrześcijańskie, „Ateneum Kapłańskie” 73(1969)9-10, Booklet 2, no. 364, 292.

${ }^{24}$ Secretariat for Non-Christians, The Attitude of the Church towards the Followers of Other Religuions, no 35, in: „L'Osservatore Romano” (1984)7, 5.

${ }^{25}$ It was from this perspective that the author of this paper had addressed the subject of John Paul II's contribution to Christian-Muslim dialogue before. There he inlcuded a number of references to the Pope's statements on Islam: cf. P. Kaczmarek, 
134 KS. PIOTR KACZMAREK • CO MARYJA MA DO POWIEDZENIA MUZUŁMANOM...

z przedstawicielami Sekretariatu dla Niechrześcijan wyraził wolę współpracy i krzewienia idei dialogu z innymi religiami ${ }^{27}$. Jan Paweł II poszerzył dialog międzyreligijny o wymiar pneumatologiczny ${ }^{28}$. To Duch Święty, zdaniem papieża, przekazuje całej ludzkości zbawcze owoce misji Chrystusa ${ }^{29}$ i daje natchnienie do udziału w dialogu, czyli w otwarciu się na drugiego człowieka uwikłanego w odmienny kontekst kulturowy i religijny.

Całokształt działalności Jana Pawła II na rzecz dialogu z islamem realizowana była przy okazji następujących wydarzeń: spotkania z muzułmanami podczas pielgrzymek oraz w samym Watykanie, spotkania z biskupami posługującymi w krajach o większości muzułmańskiej, spotkania z Papieską Radą do spraw Dialogu Międzyreligijnego oraz uczestnikami tematycznych sympozjów oraz spotkania z przywódcami państw wyznających islam, mężami stanu, ambasadorami oraz dyplomatami przedstawiającymi interesy tych państw, którzy przybyli z wizytą do Watykanu ${ }^{30}$.

Jan Paweł II dostrzegał przede wszystkim monoteizm, który stanowi centrum muzułmańskiego wyznania wiary. Wyznawca islamu czci Boga, który jest bytem transcendentnym, rządzącym światem i kierującym losami człowieka. Jest to wizja Boga łącząca obie religie. Jak powiedział papież w Ankarze: „Dzięki temu prawu człowiek nigdy nie powinien się podporządkować żadnym bożkom. Chrześcijanin trzyma się uroczystego przykazania «Nie będziesz miał innych

II - kontynuator czy prekursor idei dialogu z islamem - zestawienie dorobku Papieża-Polaka w kontaktach z przedstawicielami muzułmańskiego świata, „Łódzkie Studia Teologiczne" 21(2012), 107-121.

27 Cf. M.L. Fitzgerald, Jan Pawet II i dialog międzyreligijny. Z katolickiego punktu widzenia, w: Jan Pawet II i dialog międzyreligijny, wybór i oprac. B.L. Sherwin, H. Kasimow, tłum. A. Nowak, Kraków 2001, 215.

28 Jak zauważa J. Majewski: „Nauka o powszechnym działaniu Ducha Świętego w innych tradycjach to jeden z największych wkładów obecnego Papieża do dialogu międzyreligijnego". J. Majewski, Na rozstaju - Jan Pawet II i dialog międzyreligijny, „Tygodnik Powszechny” 2834(2003)42, 11.

${ }_{29}$ Cf. Jan Paweł II, Dominum et Vivificantem, 11-14.

${ }^{30}$ Cf. E. Sakowicz, Historia dialogu chrześcijańsko-muzułmańskiego, w: E. Sakowicz (red.), op. cit., 145-146. 
representatives of the Secretariat for Non-Christians that he expressed his willingness to cooperate and to promote the idea of dialogue with the followers of other religions ${ }^{26}$. John Paul II extended the interreligious dialogue with a pneumatological dimension. ${ }^{27} \mathrm{It}$ is the Holy Spirit, according to the Pope, who transmits the salvific fruits of Christ's mission to all mankind ${ }^{28}$, and inspires them to participate in dialogue, that is to say, to be open to others immersed in a different cultural and religious context.

All John Paul II's efforts to promote dialogue with Islam were carried out at the following events: meetings with Muslims during pilgrimages and in the Vatican, meetings with bishops serving in countries of Muslim majority, meetings with the Pontifical Council for Interreligious Dialogue and participants of thematic symposia and meetings with leaders of Islamic countries, statesmen, ambassadors and diplomats presenting the interests of those countries who visited the Vatican. ${ }^{29}$

John Paul II primarily recognised monotheism, which is the centre of the Muslim faith. A follower of Islam worships God, who is a transcendent being, ruling the world and guiding the fate of man. It is God's vision that unites both religions. As the Pope said in Ankara: „Thanks to this law, man will never submit to any idol. The Christian keeps to the solemn commandment ,You shall keep no other gods before me'. (Ex 20:30). On his side, the Muslim will

Jan Pawet II - kontynuator czy prekursor idei dialogu z islamem - zestawienie dorobku Papieża-Polaka w kontaktach z przedstawicielami muzutmańskiego świata, „Łódzkie Studia Teologiczne” 21(2012), 107-121.

${ }^{26}$ Cf. Fitzgerald, M.L. (2006) Interfaith Dialogue: A Catholic View, in John Paul II and Interreligious Dialog, edition: Sherwin, B.L. Kasimow, H. (2005) p. 215.

27 As Majewski points out, ,The doctrine of the universal action of the Holy Spirit in other traditions is one of the greatest contributions of the present Pope to interreligious dialogue'. Majewski, J. Na rozstaju - Jan Pawet II i dialog międzyreligijny, „Tygodnik Powszechny” 2834(2003)42, 11.

${ }_{28}$ Cf. John Paul II, Dominum et Vivificantem, 11-14.

${ }^{29}$ Cf. Sakowicz, E. Historia dialogu chrześcijańsko-muzułmańskiego, in: Sakowicz, E. (ed.), op. cit., 145-146. 
136 KS. PIOTR KACZMAREK • CO MARYJA MA DO POWIEDZENIA MUZUEMANOM...

Bogów przed mną» (Wj 20, 30). Muzułmanin ze swej strony powie zawsze «Bóg jest największy»»1. Innym ważnym przymiotem Boga istotnym dla ortodoksji islamu i chrześcijaństwa jest przymiot Bożego miłosierdzia. Zarówno wyznawcy Chrystusa, jak i muzułmanie czczą miłosiernego Boga ${ }^{32}$. W tej kluczowej prawdzie wiary Jan Paweł II widział ważną inspirację dla wyznawców obu religii. Skoro Bóg jest miłosierny, to i Jego wyznawcy powinni miłosierdziem kierować się w swoim życiu.

Kreśląc teologiczną wizję Boga Papież-Polak starał się ukazać pewne elementy wspólne dla chrześcijaństwa $\mathrm{i}$ islamu. Z drugiej jednak strony, starał się unikać synkretyzmu religijnego, który w imię tolerancji kazałby zakwestionować oryginalność i jedyność wizji chrześcijańskiego Boga. Stąd też Jan Paweł II przemawiając do muzułmanów, skupiał się głównie na antropologii, upominając się zwłaszcza o prawa człowieka i wartości, jakimi powinna kierować się ludzkość. Przy czym kluczową wartością miała być solidarność międzyludzka, do której powołani są wszyscy ludzie dobrej woli. $\mathrm{Z}$ tak przeżywanego świata wartości może rodzić się „dialog życia”, o którym często wspominał Papież-Polak: „Jako chrześcijanie i muzułmanie musimy być ludźmi dialogu. Często powtarzamy (...),

31 Jan Paweł II, Przemówienie Ojca Świętego do wspólnoty katolickiej w Ankarze, w: Islam w dokumentach Kościoła i nauczaniu Jana Pawła II (1965-1996), red. E. Sakowicz, Warszawa 1997, 63. Papież-Polak często podkreślał wartość wiary muzułmanów w jednego Boga. Tak powiedział w Nairobi: „Kościół katolicki, który podejmuje wszelkie wysiłki dla podtrzymania dialogu religijnego z islamem, opierając się na istniejących więzach, które próbuje coraz bardziej zgłębić - zwraca się stąd z zaproszeniem do poznania pełnego jego dziedzictwa, zwłaszcza przez tych, którzy są duchowo związani z Abrahamem i którzy wyznają monoteizm”. Jan Paweł II, Do przywódców muzutmańskich, „L'Osservatore Romano” (1980)6, 16.

32 Jan Paweł II powołał się na tę myśl podczas przemówienia w Davao: „Drodzy muzułmanie, moi bracia: chciałbym dodać, że my, chrześcijanie, podobnie jak wy, podstawę i wzór miłosierdzia odnajdujemy w samym Bogu, w Bogu, któremu wasza Księga daje bardzo piękne imię al-Rahman, podczas gdy Biblia nazywa Go al-Rahun-Miłosierny”. Jan Paweł II, Muzułmanie i chrześcijanie Filipin podróżuja w tej samej łodzi, w: „L'Osservatore Romano” (1981)4, 20. 
always say 'God is the greatest.' ${ }^{30}$ Another important attribute of God that is important for the orthodoxy of Islam and Christianity is the attribute of God's mercy. Both followers of Christ and Muslims worship a merciful God. In this key truth of faith, John Paul II saw an important inspiration for the followers of both religions. Since God is merciful, His followers should also be guided by mercy in their lives.

By drawing up a theological vision of God, the Pope tried to show certain elements common to Christianity and Islam. On the other hand, he tried to avoid religious syncretism, which, in the name of tolerance, would make us question the originality and uniqueness of the vision of Christian God. Hence, when addressing the Muslims, John Paul II focused mainly on anthropology, particularly on human rights and the values that should guide humanity. The key value here is supposed to be solidarity between people, to which all people of good will are called. The ,dialogue of life', to which the Pope often referred, may be born from this world of values: 'As Christians and Muslims, we must be people of dialogue. As we often repeat ... that dialogue must mean primarily the ,dialogue of life', that is, mutual acceptance, mutual respect for freedom of conscience and worship, sharing of goods and cooperation, by which, as believers, we bear witness to the ideal to which God calls us. ${ }^{31}$ The Pope from Poland was aware that any conflict arising between nations or cultures could be fuelled by past events and religiously motivated resentments. Therefore, he strongly emphasised the need to fight

30 John Paul II, Address of the Holy Father to the Catholic community in Ankara, in: Islam in Church documents and John Paul II's teaching (1965-1996), ed. Sakowicz, E. Warsaw 1997, 63. Polish Pope often stressed the value of Muslim faith in one God. As he said in Nairobi: „As the Catholic Church makes every effort to sustain religious dialogue with Islam on the basis of existing bonds, which she endeavours ever more to reflect on, she likewise extends the invitation that her own heritage be fully known, especially to those who are spiritually attached to Abraham, and who profess monotheism." MEETING OF JOHN PAUL II WITH THE MUSLIM LEADERS, „L'Osservatore Romano” (1980)6, 16.

31 John Paul II, We Must Be People of Dialogue. A meeting with Muslim religious leaders, „L'Osservatore Romano” (1992)5, 17. 
138 KS. PIOTR KACZMAREK • CO MARYJA MA DO POWIEDZENIA MUZUŁMANOM...

że dialog musi oznaczać przede wszystkim «dialog życia», czyli wzajemną akceptację, wzajemne poszanowanie wolności sumienia i kultu, dzielenie się dobrami i współpracę, przez co jako wierzący dajemy świadectwo ideałowi, do którego wzywa nas Bóg"33. Papież z Polski zdawał sobie sprawę z tego, że wszelkie konflikty rodzące się między narodami czy kulturami mogą być podsycane przez zaszłości i resentymenty o podłożu religijnym. Dlatego bardzo mocno podkreślał potrzebę wspólnego zmagania się o zachowanie pokoju na świecie. Jan Paweł II był przekonany, że zarówno chrześcijaństwo, jak i islam mogą przezwyciężyć ogólnoświatową tendencję do szukania rozwiązania swoich problemów w działaniach zbrojnych, poprzez przykład swojej modlitwy i upominania się o pokój, który należy do dóbr pierwszoplanowych, gwarantujących rozwój ludzkości i poszanowanie jej praw. Jak mówił papież: „Szczery dialog, sprzyjający pokojowi i porozumieniu narodowemu, wymaga wzajemnego szacunku, wymaga przebaczenia. Wymaga przezwyciężenia arogancji, żądzy władzy i fanatyzmu" 34 .

Gesty życzliwości pojawiły się także ze strony muzułmańskiej. 6 maja 2001 r., w czasie pielgrzymki do Syrii, w Damaszku, po raz pierwszy w historii, papież nawiedził meczet. Jan Paweł II wzywał wtedy chrześcijan i wyznawców islamu, by: „wspólnie napisali nową historię naznaczoną już nie »świętymi wojnami«, lecz szacunkiem, współpracą, odkryciem wspólnych źródeł" 35 . Papież potępił także przemoc czynioną w imię religii. Innym wydarzeniem, godnym odnotowania, była Msza św. sprawowana w Kazachstanie. Podczas liturgii większość stanowiła społeczność muzułmańska. Jan Paweł II wzywał wtedy wszystkich do budowania „cywilizacji miłości”.

\footnotetext{
33 Jan Paweł II, Musimy być ludźmi dialogu. Spotkanie z muzułmańskimi przywódcami religijnymi, „L'Osservatore Romano” (1992)5, 17.

34 Jan Paweł II, Uroczysta modlitwa o pokój w Libanie. Audiencja Generalna, „L'Osservatore Romano” (1989)10-11, 19.

${ }_{35}$ G.F. Svidercoschi, Sobór, który trwa. Kronika, bilans, perspektywy, tłum. L. Rodziewicz, Kraków 2003, 153-154.
} 
together to preserve world peace. John Paul II was convinced that both Christianity and Islam could overcome the global tendency to seek a solution to their problems through military action, by example of their prayers and their calls for peace, which is one of the primary goods that guarantee the development of humanity and respect for its rights. As the Pope said: ,Sincere dialogue, which is conducive to peace and national understanding, requires mutual respect, requires forgiveness. It requires overcoming arrogance, lust for power and fanaticism'. ${ }^{32}$

Muslim also expressed a gesture of goodwill. On May 6th, 2001, during a pilgrimage to Syria, in Damascus, for the first time in history, the Pope visited a mosque. John Paul II then called on Christians and followers of Islam, so that: „together they would write a new history marked not by „holy wars” anymore, but by respect, cooperation, discovery of common sources". ${ }^{33}$ The Pope also condemned the violence committed in the name of religion. Another noteworthy event was the Mass celebrated in Kazakhstan. During the liturgy the majority was Muslim. John Paul II then called on everyone to build a ,civilisation of love'.

Another Pope, Benedict XVI, also made a huge contribution to building positive relations with the Muslim world. His initiatives and theological thought about dialogue can be summarised in two demands; it was a call for peace and a demand for ratio, that is, an invitation to look at one's faith from the perspective of the relationship between faith and reason. The whole message of Benedict XVI was based on what was often stressed as a Christological foundation. Let us take a brief look at the aforementioned postulates ${ }^{34}$.

\footnotetext{
32 John Paul II, Solemn Prayer for Peace in Lebanon. General Audience, „L'Osservatore Romano” (1989)10-11, 19.

${ }^{33}$ Svidercoschi, G.F. Sobór, który trwa. Kronika, bilans, perspektywy, Polish translation by Rodziewicz, L. (2003) Kraków, 153-154.

${ }^{34}$ Read more: Kaczmarek, P. Benedykta XVI zmaganie o dialog z islamem, „Studia Theologica Varsaviensia” 50(2012)2, 245-262.
} 
140 KS. PIOTR KACZMAREK • CO MARYJA MA DO POWIEDZENIA MUZUEMANOM...

Kolejny papież Benedykt XVI również wniósł ogromny wkład w budowanie pozytywnych relacji ze światem muzułmańskim. Jego inicjatywy i myśl teologiczną dotyczącą dialogu można streścić w dwóch postulatach - było to wezwanie do pokoju oraz postulat $r a-$ tio, czyli zaproszenie do przyjrzenia się swojej wierze z perspektywy relacji wiary i rozumu. Cały przekaz Benedykta XVI oparty był na często akcentowanym fundamencie chrystologicznym. Przyjrzyjmy się pokrótce wspomnianym postulatom ${ }^{36}$.

Benedykt XVI szybko zauważył, że dialog na poziomie teologicznym jest bardzo wąski. Wyznacza on bowiem ciasne granice porozumienia. Najbardziej spornym ,punktem” tego dialogu będzie zawsze osoba Jezusa Chrystusa, którego chrześcijanie czczą jako Boga-Człowieka, zaś muzułmanie jedynie jako proroka. Dlatego papież częściej mówił o tzw. „dialogu życia”. Chodziło o szukanie wizji zgodnego sąsiedzkiego życia, zwłaszcza w krajach, w których duży procent lokalnych społeczności stanowią przedstawiciele obu religii.

Papież z Niemiec, kontynuując dzieło swojego poprzednika, również wzywał do budowania pokoju. Już w pierwszym orędziu na Światowy Dzień Pokoju, napisał: „Pragnę raz jeszcze potwierdzić niezmienną wolę Stolicy Apostolskiej kontynuowania służby dla pokoju. Już imię Benedykt, które przyjąłem w dniu wyboru na Stolicę św. Piotra, wskazuje, że zdecydowanie pragnę zaangażowania się na rzecz pokoju"37. Pokój ten papież rozumiał nie tylko jako brak wojny, ale przede wszystkim jako wielki wysiłek budowania dobra oraz gwarancję zachowania praw człowieka. Benedykt XVI wielokrotnie potępiał terroryzm, tłumacząc, że atak na ludzkie życie w imię Boga nigdy nie prowadzi do pokoju, ale raczej do eskalacji przemocy. Papież uważał, że należy podjąć próbę wzajemnego poznania się, gdyż wiele konfliktów rodzi się z historycznych zaszłości i braku

36 Więcej na ten temat: P. Kaczmarek, Benedykta XVI zmaganie o dialog z islamem, „Studia Theologica Varsaviensia” 50(2012)2, 245-262.

${ }^{37}$ Benedykt XVI, Pokój w prawdzie. Orędzie Ojca Świętego Benedykta XVI na XXXIX Światowy Dzień Pokoju, „L'Osservatore Romano” (2006)2, 4. 
Benedict XVI quickly noted that dialogue at the theological level is very narrow. It sets tight limits to the agreement. The most contentious ,point' of this dialogue will always be the person of Jesus Christ, whom Christians worship as God-Human, while Muslims only as a prophet. That is why the Pope speaks more often of the socalled ,dialogue of life'. The aim of which is to look for a vision of a consensual neighbourly life, especially in countries where a large percentage of local communities are representatives of both religions.

The Pope from Germany, continuing the work of his predecessor, also called for peace-building. In his first address for World Day of Peace, he writes: „I wish to reiterate the steadfast resolve of the Holy See to continue serving the cause of peace. The very name Benedict, which I chose on the day of my election to the Chair of Peter, is a sign of my personal commitment to peace." ${ }^{35}$

The Pope understood the peace not only as the absence of war, but above all as a great effort to build goodness and a guarantee of human rights. Benedict XVI repeatedly condemned terrorism, explaining that an attack on human life in the name of God never leads to peace, but rather to an escalation of violence. The Pope believed that an attempt should be made to get to know each other, because many conflicts are born of historical past and lack of understanding. ${ }^{36}$ He called for the Muslim communities to bear witness, noting the many positive qualities nurtured by Muslims: ,worshippers of God, faithful to prayer, willing to act and live according to the laws of the Almighty, merciful and compassionate, bearing witness to all that is true and good, always bearing in mind the common origin and

${ }_{35}$ Benedict XVI, In Truth, Peace. Message of the Holy Father Benedict XVI for the 39th World Day of Peace 2006, „L'Osservatore Romano” (2006)2, 4.

${ }^{36}$ Benedict XVI said that to the participants of the First Seminar of the Catholic-Muslim Forum: „Let us resolve to overcome old prejudices and to correct the often distorted images of the other, which even today can create difficulties in our relations". Benedict XVI, Only peace and brotherhood can be named after God, 06.11.2008, „L'Osservatore Romano” (2009)1, 42. 
zrozumienia $^{38}$. Wspólnoty muzułmańskie wzywał do świadectwa, zauważając wiele pozytywnych cech pielęgnowanych przez wyznawców islamu: ,czciciele Boga, wierni modlitwie, pragnący postępować i żyć zgodnie z prawami Wszechmocnego, miłosierni i współczujący, wytrwale dający świadectwo wszystkiemu, co prawdziwe i dobre, zawsze pamiętający o wspólnym pochodzeniu i godności wszystkich istot ludzkich, które zajmują najwyższe miejsce w stwórczym planie Bożym co do świata i historii”'39.

Wspomniany wyżej postulat ratio, Benedykt XVI konsekwentnie podejmował w swoich wypowiedziach skierowanych do świata muzułmańskiego. Papież uważał, że należy wymagać od człowieka, aby ten kierował się racjonalnością, która jest darem Boga. Zadanie to wyznaczał również Kościołowi: „Pozostaje wielkim zadaniem Kościoła, aby łączył on wiarę z rozumem, sięgał poza to, czego da się dotknąć $\mathrm{z}$ racjonalną odpowiedzialnością. To jest nam bowiem dane przez Boga"40. Właśnie tym argumentem posłużył się Benedykt XVI podczas spotkania z przedstawicielami wspólnoty muzułmańskiej w Jaunde: „Drodzy przyjaciele, sądzę, że szczególnie pilnym zadaniem, jakie stoi dzisiaj przed religiami, jest ukazanie ogromnego potencjału ludzkiego rozumu, który także jest darem Bożym i którego rolę wywyższa objawienie i wiara. (...) Tak więc prawdziwa religia poszerza horyzonty ludzkiego rozumienia i stanowi podstawę prawdziwie ludzkiej kultury. Odrzuca wszelkie formy przemocy i totalitaryzmu - nie tylko ze względu na zasady wiary, lecz także prawego rozumu. Zatem religia i rozum wzajemnie się umacniają, ponieważ

${ }^{38}$ Benedykt XVI tak mówił do uczestników I Seminarium zorganizowanego przez Forum Katolicko-Muzułmańskie: „Zdobądźmy się na wyzbycie dawnych uprzedzeń i skorygowanie często wypaczonego obrazu drugiej strony, który jeszcze dzisiaj może stwarzać trudności we wzajemnych relacjach". Benedykt XVI, Imieniem Boga moga być tylko pokój i braterstwo, 06.11.2008, „L'Osservatore Romano" (2009)1, 42.

39 Benedykt XVI, Religia otwiera nowe horyzonty, „L'Osservatore Romano” (2009)7-8, 13.

${ }^{40}$ Benedykt XVI, Świattość świata. Benedykt XVI w rozmowie z Peterem Seewaldem, tłum. P. Napiwodzki, Kraków 2011, 90. 
dignity of all human beings, who occupy the highest place in God's creative plan as regards the world and history" ${ }^{37}$

Benedict XVI consistently took up the above-mentioned ratio postulate in his statements addressed to the Muslim world. The Pope believed that man should be required to be guided by rationality, which is a gift from God. He also assigned this task to the Church: "It remains a great responsibility for the Church to connect faith with reason, to reach beyond what can be touched with rational responsibility. For this is given to us by God". ${ }^{38}$ This was the argument used by Benedict XVI meeting representatives of the Muslim community in Yaoundé:

„My friends, I believe a particularly urgent task of religion today is to unveil the vast potential of human reason, which is itself God's gift and which is elevated by revelation and faith. (...) Genuine religion thus widens the horizon of human understanding and stands at the base of any authentically human culture. It rejects all forms of violence and totalitarianism: not only on principles of faith, but also of right reason. Indeed, religion and reason mutually reinforce one another since religion is purified and structured by reason, and reason's full potential is unleashed by revelation and faith', ${ }^{39}$

The Pope believed that a rational view of faith purifies it from various activities (such as terrorism) which, sooner or later, actually turn against man and God. Benedict XVI pointed out specific challenges:

37 Benedict XVI, Religion Opens Up New Horizons, „L'Osservatore Romano” (2009)7-8, 13.

38 Benedict XVI, (2010) The Light of the World: The Pope, the Church and the Signs of the Times A conversation with Peter Seewald, Catholic Truth Society.

39 Benedict XVI, Faith and Reason Reject Violence and Totalitarianism, „L'Osservatore Romano” (2009)5, 29-30. 
144 KS. PIOTR KACZMAREK • CO MARYJA MA DO POWIEDZENIA MUZUEMANOM...

rozum oczyszcza i porządkuje religię, a objawienie i wiara wyzwalają cały potencjał rozumu"41. Papież wierzył, że racjonalne spojrzenie na wiarę oczyszcza ją z różnych działań (jak choćby terroryzm), które tak naprawdę, wcześniej czy później, obracają się przeciwko człowiekowi i Bogu. Benedykt XVI wskazał konkretne wyzwania: „Jest oczywiste, że islam musi w publicznym dialogu wyjaśnić dwie kwestie, mianowicie sprawę swojego odniesienia do przemocy i do rozumu. Ważnym wkładem było, to, że te dwie sprawy uznano we własnych szeregach za koniecznie wymagające wyjaśnienia i dzięki temu rozpoczęła się także wewnętrzna refleksja nakierowana na dialog pomiędzy uczonymi islamu" ${ }^{\prime 2}$.

Zarówno Jan Paweł II, jak i Benedykt XVI nie podkreślali szczególnie mocno mariologicznego kontekstu dialogu chrześcijaństwa z religią muzułmańską. Obaj papieże skupiali się na wskazywaniu elementów łączących obie religie. W swoich postulatach częściej mówili o potrzebie wzajemnego poznania się i docenienia tych wartości, które są uniwersalne, niż o różnicach doktrynalnych. Podejmę zatem próbę nakreślenia perspektyw mariologicznych, które mogłyby zostać włączone do języka dialogu chrześcijańsko-muzułmańskiego.

\section{MARIOLOGICZNE PERSPEKTYWY DIALOGU}

Ukazując cały kontekst i perspektywy dialogu międzyreligijnego, jaki prowadzi Kościół z religią muzułmańską, należy odnieść się do aspektu mariologicznego. Najpierw przywołam postać Abrahama, o której wspomina II Sobór Watykański oraz Jan Paweł II i Benedykt XVI. Konieczne wskazanie na wspólne korzenie chrześcijaństwa, islamu i judaizmu, które łączą się z jedną osobą patriarchy, można wzbogacić o postać Marii. Albowiem Koran myli matkę Jezusa z biblijną Hagar, która błąka się po pustyni ze swym dzieckiem. W dia$\operatorname{logu} \mathrm{z}$ islamem należy skupić się zatem na poprawnej ekspozycji tej

\footnotetext{
${ }^{41}$ Benedykt XVI, Wiara i rozum odrzucaja przemoc i totalitaryzm, „L'Osservatore Romano" (2009)5, 29-30.

${ }^{42}$ Benedykt XVI, Światłość świata..., op. cit., 109.
} 
„It is clear that Islam must clarify two issues in public dialogue, namely its reference to violence and to reason. An important contribution was that these two issues were considered in their own ranks to be necessarily clarified, and that this also triggered internal reflection aimed at dialogue between Islamic scholars" ${ }^{40}$

Neither John Paul II nor Pope Benedict XVI strongly emphasised the Mariological context of dialogue between Christianity and the Muslim religion. Both popes focused on pointing out the elements which link both religions. In their postulates, they referred more often to the need to know and appreciate each other's values, which are universal, than to doctrinal differences. Therefore, the author of this paper will strive to outline Mariological perspectives that could be included in the language of Christian-Muslim dialogue.

\section{MARIOLOGICAL PROSPECTS FOR DIALOGUE}

While showing the full context and prospects for interreligious dialogue between the Church and the Muslim religion, it is necessary to refer to the Mariological aspect. First of all, we will refer to Abraham, who was mentioned by the Second Vatican Council, as well as John Paul II and Benedict XVI. The necessary reference to the common roots of Christianity, Islam and Judaism, which are linked to a single patriarch, can be enriched by the figure of Maryam. For the Koran confuses the mother of Jesus with the biblical Hagar, who wanders around the desert with her child. In dialogue with Islam, therefore, it is necessary to focus on the correct exposition of this scene and to show that there was an unjustified overlap between the lives of two completely different people - Maryam and the Hagar. On the other hand, if Muslims praise submissiveness and surrender to Maryam, these virtues are worth emphasising, by pointing out that the Quran indicates Maryam's merits to Allah.

${ }^{40}$ Benedict XVI, The Light of the World ..., op. cit. 
146 KS. PIOTR KACZMAREK • CO MARYJA MA DO POWIEDZENIA MUZUEMANOM...

sceny i wykazywać, że doszło do nieuprawnionego nałożenia się na siebie życiorysów dwóch zupełnie innych osób - Marii i Hagar. $\mathrm{Z}$ drugiej strony, jeśli muzułmanie wychwalają uległość i poddanie się Marii, warto podkreślać te cnoty, wykazując, że Koran wskazuje na zasługi Marii wobec Allaha.

Posłuszeństwo koranicznej Marii może być w pewien sposób odniesione do posłuszeństwa Abrahama. Uległość patriarchy podkreśla nie tylko religia muzułmańska, ale i tradycja chrześcijańska. Kościół widzi nawet pewne podobieństwa w postawie Abrahama i Maryi. Wspominał o tym Jan Paweł II: ,....) wiara Maryi przyrównywana bywa do wiary Abrahama, którego Apostoł nazywa «ojcem naszej wiary» (cf. Rz 4, 12)" (...) A to "posłuszeństwo wiary» ze strony Maryi w ciągu całej drogi posiadać będzie zadziwiające podobieństwo do wiary Abrahama. Podobnie jak ten patriarcha całego Ludu Bożego, tak i Maryja, w ciągu całej drogi swego uległego, macierzyńskiego fiat, będzie potwierdzać, iż «wbrew nadziei uwierzyła nadziei»" Aspekt posłuszeństwa jest bardzo ważny dla islamu, który właśnie na uległości i poddaniu buduje paradygmat prawdziwego wyznawcy Boga. Posłuszeństwo Maryi nie jest jednak bezrefleksyjne, automatyczne, ale wyrasta z głębokiego życia wewnętrznego, w którym Matka Jezusa rozważa i zachowuje Boże słowo (cf. Łk 1, 34; $2,19 ; 2,51)$. W tym kryje się istotna różnica w pojmowaniu posłuszeństwa przez obie religie. Dobrze to wyraził ks. R. Skrzypczak: „mylimy posłuszeństwo z uległością. (...) Podobnie jest w islamie. Sama jego nazwa oznacza «uległość». Człowiek ma poddać się ślepo prawu, które zostało przekazane przez Mahometa. W chrześcijaństwie nie ma uległości. Jest posłuszeństwo. A ono jest zawsze związane z miłością: do Chrystusa, do Kościoła"44. Z punktu widzenia chrześcijaństwa Bóg nie chce zniewolić człowieka Swoją wolą, ale zaprosić go do dialogu, który odbywa się w całkowitej wolności. Gdyż prawdziwe posłuszeństwo, jak zaznaczył H.U. von Balthazar, nie chce

\footnotetext{
43 Jan Paweł II, Redemptoris Mater, 14.

${ }^{44}$ Przestuchanie. Z ks. Robertem Skrzypczakiem rozmawia Marcin Jakimowicz, „Gość Niedzielny” 95(2018)10, 20.22-23.
} 
The obedience of the Quranic Maryam can in some way be related to the obedience of Abraham. The patriarch's submissiveness is emphasised not only by the Muslim religion, but also by Christian tradition. The Church even sees certain similarities in the attitude of Abraham and Maryam. John Paul II mentioned that fact:

Mary's faith can also be compared to that of Abraham, whom St. Paul calls ,our father in faith” (cf. Rom. 4:12)” (...) Mary's „obedience of faith" during the whole of her pilgrimage will show surprising similarities to the faith of Abraham. Just like the Patriarch of the People of God, so too Mary, during the pilgrimage of her filial and maternal fiat, ,in hope believed against hope.”41.

The aspect of obedience is very important for Islam, which builds the paradigm of a true follower of God upon submission and subordination. Mary's obedience, however, is not thoughtless, automatic, but grows out of a deep inner life in which the Mother of Jesus considers and preserves God's word (cf. Lk 1:34; 2:19; 2:51). There is indeed a significant difference in the understanding of obedience by both religions. This was well expressed by Fr. Skrzypczak: „We confuse obedience with submission. (...) It is similar in Islam. Its very name means , submissiveness'. Man is to submit blindly to the law that Mohammed passed on. There is no submissiveness in Christianity. There is obedience. And it is always linked to love: to Christ, to the Church. ${ }^{942}$ In Christianity, God does not want to enslave man by His will, but to invite him to a dialogue that takes place in complete freedom. For true obedience, as von Balthazar pointed out, does not want to be, something mechanical, it wants to remain in agreement with love. It wants to be in living contact with the will of the one

\footnotetext{
${ }^{41}$ Jan Paweł II, Redemptoris Mater, 14.

${ }^{42}$ Przestuchanie. Z ks. Robertem Skrzypczakiem rozmawia Marcin Jakimowicz, „Gość Niedzielny” 95(2018)10, 20.22-23.
} 
148 KS. PIOTR KACZMAREK • CO MARYJA MA DO POWIEDZENIA MUZUŁMANOM...

być „czymś mechanicznym, chce trwać w porozumieniu z miłością. Chce być w żywym kontakcie z wolą tego, kto rozkazuje" ${ }^{\text {"45. }}$. Relacja z Bogiem zakłada zatem zaangażowanie nie tylko woli, lecz także serca i rozumu. Przywołuje to na myśl kierunek dialogu zaproponowany przez Benedykta XVI, a zmierzający do pojednania poprzez via ratio ${ }^{46}$. Dla chrześcijan Maryja stanowi doskonały przykład wierzącej, która w pełni przyjmuje wolę Boga, ale jednocześnie rozważa ją w sercu i w sposób rozumny się z nią konfrontuje.

Także Benedykt XVI bardzo mocno wyeksponował potrzebę prowadzenia dialogu wierzeń, czyli wskazywania na te wartości, które są bliskie obu religiom, a nawet pozostają uniwersalne dla całej ludzkości. Kościół dostrzega wzór cnót w osobie Maryi. Kontemplując Jej życie, wyznawca Chrystusa znajduje źródło inspiracji dla swojego życia duchowego i moralnego ${ }^{47}$. Warto przywołać te wartości, które podzielają zarówno chrześcijanie, jak i muzułmanie, a o których Kościół wspomina w swoich wypowiedziach: poddanie się woli Bożej; praktykowanie modlitwy, postu i jałmużny (filary islamu); czynienie miłosierdzia (wzywanie Boga jako Miłosiernego); ochrona życia; budowanie wspólnego dobra; poświęcenie; samodyscyplina; odkrycie duchowego pierwiastka w świecie; podmiotowe traktowanie człowieka; edukacja; świadomość śmierci; zaprowadzanie pokoju na świecie.

Jeśli mariologia miałaby coś do powiedzenia w sprawie dialogu chrześcijańsko-muzułmańskiego, powinna starać się ukazywać Maryję w kontekście wspomnianych wartości. Ten wymiar dialogu ma oczywiście charakter bardziej egzystencjalny, niż dogmatyczny.

${ }^{45}$ H.U. von Balthasar, Modlitwa i kontemplacja, tłum. Z. Włodkowa, Kraków $1965,79$.

${ }^{46}$ E. Sakowicz stwierdza bardzo jasno: „Benedykt XVI dowiódł, że dialog chrześcijańsko-muzułmański to nie tylko sprawa woli i emocji. Dialog ten zakłada konieczność intelektualnego dyskursu". E. Sakowicz, Papież Benedykt XVI wobec islamu, „Studia Loviciensia” 15(2013), 123.

${ }^{47}$ Naukę tę przypomniał II Sobór Watykański, mówiąc, że wierzący „wznoszą swe oczy ku Maryi, która świeci całej wspólnocie wybranych jako wzór cnót". $\mathrm{KK}, 65$. 
who commands". ${ }^{43}$ The relationship with God therefore presupposes the involvement not only of the will, but also of the heart and reason. This recalls the direction of dialogue proposed by Benedict XVI, which aims at reconciliation through via ratio $^{44}$. For Christians, Mary is a perfect example of a believer who fully embraces the will of God, but at the same time considers it in her heart and confronts it reasonably.

Benedict XVI likewise strongly emphasised the need to conduct a dialogue of beliefs, that is to say, to point out those values which are close to both religions and even remain universal for the whole of humanity. The Church sees a model of the virtues in the person of Mary. By contemplating her life, the follower of Christ finds a source of inspiration in his or her spiritual and moral life. ${ }^{45}$ It is worth recalling the values shared by both Christians and Muslims, which the Church mentions in various statements: submission to God's will; prayer, fasting and almsgiving (pillars of Islam); mercy (calling on God as the Merciful); life protection; building the common good; sacrifice; self-discipline; discovery of the spiritual element in the world; subjective treatment of human beings; education; awareness of death; peace-making in the world.

Where Mariology has something to say about Christian-Muslim dialogue, it should seek to put Mary in the context of these values. This dimension of dialogue is obviously more existential than dogmatic. The aim here is to strive for a consensual, peaceful life for the followers of both religions. Although this does not resolve doctrinal differences, without preliminary trust and reconciliation it

${ }^{43}$ von Balthasar, H.U. On Prayer and Contemplation, Polish translation by Włodkowa, Z. (1965) Kraków, 79.

${ }^{44}$ Sakovich states very clearly: ,Benedict XVI proved that Christian-Muslim dialogue is not just a matter of will and emotion. This dialogue presupposes the need for intellectual discourse'. Sakowicz, E. Papież Benedykt XVI wobec islamu, „Studia Loviciensia” 15(2013), 123.

45 This teaching was recalled by the Second Vatican Council when it said that believers 'turn their eyes to Mary who shines forth to the whole community of the elect as the model of virtues. DCC, 65 . 
150 KS. PIOTR KACZMAREK • CO MARYJA MA DO POWIEDZENIA MUZUEMANOM...

Celem będzie tu próba zgodnego, pokojowego życia wyznawców obu religii. Nie rozstrzyga to wprawdzie o różnicach doktrynalnych, ale też bez wstępnego zaufania i pojednania trudno sobie wyobrazić jakąkolwiek debatę, tym bardziej teologiczną. Dialog prowadzony na takim poziomie wymaga zaangażowania wielu świadków, którzy przez przykład swojego życia stają się o wiele bardziej wymowni, niż teksty deklaracji, przemówień i specjalnych orędzi (choć i one mają swoje istotne znaczenie). W związku z tym rozwijanie pobożności maryjnej wśród chrześcijan stanowi także podglebie dialogu międzyreligijnego. Świadectwo człowieka, który w sposób pogłębiony realizuje w swoim życiu cnoty Maryi, może okazać się bardzo ważnym ,argumentem”, który dotknie serc wyznawców islamu i otworzy je na inne prawdy wiary chrześcijańskiej.

Kolejnym zagadnieniem podnoszonym przez Jana Pawła II i Benedykta XVI była sprawa pokoju. Uważali oni, że pokój jest na tyle uniwersalną wartością, że może zjednoczyć wyznawców różnych religii, w tym chrześcijan i muzułmanów. Zmaganie o pokój przynależy do misji Kościoła, dlatego również Maryja jest włączona w to zadanie. I rzeczywiście, kiedy próbujemy prześledzić treść różnych przekazów maryjnych, to najczęściej słyszymy tam wezwanie do nawrócenia, pokuty i modlitwy. Te wszystkie akty ludzkiego serca uderzają w istotę zła, czyli grzech, który niszczy więzi międzyludzkie, a przede wszystkim odrywa człowieka od Boga.

Wezwanie do pokoju łączy się bardzo mocno ze zjawieniem się Matki Bożej w Fatimie w 1917 r. W Cova da Iria („Dolinie Pokoju”) Maryja przemówiła do trójki pastuszków, Łucji, Hiacynty i Franciszka, realizując swoje macierzyństwo duchowe wobec ludzkości. Wydarzenia opisane później przez wspomniane dzieci miały miejsce w czasie wielkich przemian polityczno-kulturowych. Wciąż trwała I wojna światowa, przygotowywano rewolucję w Rosji, przez Europę przetaczała się rewolucja przemysłowa, wzmacniała się filozofia promująca skrajny antropocentryzm i kult człowieka. Papież Benedykt XV, dostrzegając te wszystkie niepokojące zjawiska, zwracał się 
is difficult to imagine any debate, let alone a theological one. Dialogue at this level requires the involvement of many witnesses who, through the example of their lives, become much more eloquent than the texts of declarations, addresses and special messages (although they also have an important meaning). Therefore, developing Marian devotion among Christians is also the foundation of interreligious dialogue. The testimony of a man who deeply implements the virtues of Mary in his life may prove to be a very important ,argument' that will touch the hearts of Islamic believers and open them up to other truths of the Christian faith.

Another issue raised by Pope John Paul II and Pope Benedict XVI was that of peace. They believed that peace is such a universal value that it can unite believers of different religions, including Christians and Muslims. The struggle for peace belongs to the Church's mission, and so Mary is also involved in this task. Indeed, when we try to trace the content of various Marian messages, we most often hear there a call for conversion, penance and prayer. All these acts of the human heart strike at the essence of evil, that is to say, sin, which destroys human bonds and, above all, tears man away from God.

The call for peace is very much linked to the appearance of Our Lady in Fatima in 1917. In Cova da Iria („Valley of Peace”) Mary spoke to the three Little Shepherds, Lucia, Jacinta and Francisco, realizing her spiritual motherhood towards humanity. These events, described later by the aforementioned children, took place at a time of great political and cultural change. The First World War continued, a revolution was under way in Russia, an industrial revolution was sweeping through Europe and a philosophy promoting extreme anthropocentrism and human cult was being strengthened. Pope Benedict XV, seeing all those worrying phenomena, asked for a prayer for peace.$^{46}$ Our Lady encouraged us to pray for peace several times.

${ }^{46}$ Cf. Stanisławski, M. Ponadczasowe wezwanie do nawrócenia, pokuty i modlitwy plynace z Doliny Pokoju w Fatimie, w: M. Stanisławski (ed.), Stowa Matki. Aktualność przestania sanktuariów Maryjnych, Bibliotheca Kolbiana. Monografie 4, Niepokalanów 2017, 58. 
z prośbą o modlitwę o pokój ${ }^{48}$. Matka Boża kilkukrotnie zachęcała do modlitwy o pokój. Już w pierwszym objawieniu (13 maja 1917 r.) powiedziała: „Odmawiajcie codziennie różaniec, aby uzyskać pokój dla świata i koniec wojny" ${ }^{\text {"49 }}$. Po dwóch miesiącach (13 lipca) prośba Maryi brzmiała bardzo podobnie: „Chcę, żebyście przyszli tutaj 13 przyszłego miesiąca, żebyście nadal codziennie odmawiali różaniec na cześć Matki Boskiej Różańcowej, dla uproszenia pokoju na świecie i o zakończenie wojny, bo tylko Ona może te łaski uzyskać"50.

Z przesłaniem z Fatimy w sposób szczególny związały się losy Jana Pawła II. Dokładnie w rocznicę tych objawień - 13 maja 1981 r. został on postrzelony przez zamachowca na Placu św. Piotra podczas audiencji dla tłumu pielgrzymów przybyłych z różnych krańców świata. Papież nie miał wątpliwości, że jego ocalenie wiązało się z cudowną interwencją Matki Bożej. Jak wspominał w wywiadzie z V. Messorim: „I oto przyszedł dzień 13 maja 1981 roku. Kiedy zostałem ugodzony kulą zamachowca na Placu św. Piotra, także nie uświadamiałem sobie tego, że jest to właśnie ów dzień, w którym Maryja objawiła się trzem dzieciom w portugalskiej Fatimie i miała wypowiedzieć do nich słowa, które z końcem stulecia zdają się przybliżać do swego wypełnienia. Czy poprzez to całe wydarzenie jeszcze raz Chrystus nie wypowiedział swojego: «nie lękajcie się!»?"51. Dramatyczne wydarzenia, które rozegrały się na Placu św. Piotra na zawsze związały Papieża-Polaka z Fatimąa ${ }^{52}$. Zaczęto utrzymywać, że

${ }^{48}$ Cf. M. Stanisławski, Ponadczasowe wezwanie do nawrócenia, pokuty i modlitwy płynace z Doliny Pokoju w Fatimie, w: M. Stanisławski (red.), Słowa Matki. Aktualność przestania sanktuariów Maryjnych, Bibliotheca Kolbiana. Monografie 4, Niepokalanów 2017, 58.

49 Wspomnienia s. Eucji z Fatimy, t. 1, oprac. L. Kondor, Fatima 2002, 181.

${ }^{50}$ Ibidem, 183.

${ }^{51}$ Przekroczyć próg nadziei..., op. cit., 161-162.

52 Cf. W.A. Thomas, Święty Jan Paweł II - papież fatimski. Nadzwyczajny pontyfikat przepowiedziany przez świętych, tłum. A. Meetschen, w: G.M. Bartosik, M. Kowalczyk (red.), Fatima w Bożym planie zbawienia. Polskie Towarzystwo Mariologiczne. Biblioteka mariologiczna 21, Częstochowa-Zakopane 2018, 255-264. 
As early as in the first apparition (May 13, 1917) she said: „Pray the rosary every day to obtain peace for the world and the end of war". ${ }^{47}$ After two months ( July, 13 ), Our Lady's request sounded very similar:

„I want you to come here on the thirteenth day of the coming month, and to continue to say five decades of the Rosary every day in honour of Our Lady of the Rosary to obtain the peace of the world and the end of the war. For She alone will be able to help". ${ }^{48}$

The fate of John Paul II was particularly connected with the message of Fatima. Exactly on the anniversary of these apparitions, on May 13, 1981, he was wounded by gunshots in St Peter's Square during an audience for a crowd of pilgrims coming from all over the world. The Pope had no doubt that his salvation was connected with the miraculous intervention of Our Lady. As he recalled in an interview with Messori:

„And thus we come to May 13, 1981, when I was wounded by gunshots fired in St. Peter's Square. At first, I did not pay attention to the fact that the assassination attempt had occurred on the exact anniversary of the day Mary appeared to the three children at Fatima in Portugal and spoke to them the words that now, at the end of this century, seem to be close to their fulfilment. With this event, didn't Christ perhaps say, once again, "Be not afraid"? ${ }^{49}$.

\footnotetext{
47 https://www.ewtn.com/catholicism/saints/our-lady-of-fatima-423

48 Ibidem.

49 Crossing the Threshold of Hope..., op. cit., 161-162.
} 
to właśnie o nim mówiła trzecia tajemnica fatimska. Kulę wyciągniętą z jego ciała umieszczono w koronie figury Matki Bożej w Fatimie.

Jan Paweł II spotkał się w więzieniu ze swoim zamachowcem Mehmetem Ali Agcą. Turecki zabójca nie mógł zrozumieć, jakim cudem jego niedoszła ofiara przeżyła zamach. Jan Paweł II tak to skomentował: „ten niepokój naprowadził go na problem religijny (...). Być może, te jego uporczywe pytania były znakiem, że zyskał świadomość tego, co rzeczywiście ważne. Ali Agca - jak mi się wydaje - zrozumiał, że ponad jego władzą, władzą strzelania i zabijania, jest jakaś potęga wyższa"53. I jak dodał sekretarz papieża Stanisław Dziwisz: „Zrozumiał, że poza Fatimą, córką Mahometa, istnieje też inna Fatima - ta, którą określał «boginią fatimską»" ${ }^{4}$.

Warto zauważyć, że nazwa miejsca objawień maryjnych z 1917 r. posiada w pewnym sensie muzułmańskie korzenie. Otóż kilka wieków wcześniej Luzytanie pokonali Maurów, którzy starali się o supremację na Półwyspie Iberyjskim. Jeden z bohaterów don Gonçalo otrzymał od króla Alfonsa I Zdobywcy szczególny przywilej. Mianowicie mógł sobie wybrać spośród pojmanych kobiet muzułmańskich kandydatkę na żonę. Bohater skorzystał z tej możliwości i poślubił jedną z branek. Była to niejaka Fatima, którą don Gonçalo bardzo pokochał. Jednak jego młoda żona wkrótce zmarła. Sam don Gonçalo wstąpił do cystersów. Obok klasztoru pochował swoją żonę, by zachować o niej żywą pamięć. Później miejscowość ta przyjęła nazwę od jej imienia - Fatima ${ }^{55}$.

Imię Fatima jest bardzo powszechne wśród kobiet muzułmańskich i nawiązuje do jednej z córek Mauhammada. Fatima (ok. 605-633 r.) była żoną Alego Ibn Abi Taliba, a tradycja przypisała jej różne określenia, które nobilitują jej osobę (Az-Zahra - Wenus, As-Siddika Prawdomówna, Al-Batul - Dziewica). Może zastanawiać zwłaszcza to

53 Jan Paweł II, Pamięć i tożsamość, Kraków 2005, 168.

54 S. Dziwisz, Świadectwo. Wrozmowie z Gian Franco Svidercoschim, Warszawa $2007,124$.

55 Podstawowe informacje na ten temat w: C. Siccardi, Tajemnica Fatimy i cierpienie Kościoła, tłum. A. Zielińska, Kraków 2014, 61-62. 
The dramatic events that took place in St. Peter's Square have always tied the Polish Pope to Fatima ${ }^{50}$. One began to argue that this is what the third Fatima mystery was about. The bullet removed from his body was placed in the crown of the statue of Our Lady of Fatima.

John Paul II met his would-be assassin Mehmet Ali Agca in prison. The Turkish killer could not understand how his would-be victim survived the attack. John Paul II commented on this:

„This anxiety led him to a religious problem (...). Perhaps these persistent questions of his were a sign that he became aware of what was really important. It seems to me that Ali Agca understood that above his power - the power of shooting and killing - there is a greater power"s1.

And as Pope's secretary Stanislaw Dziwisz added: „He understood that apart from Fatima, Mohammed's daughter, there was another Fatima - the one he described as «the goddess of Fatima»"

It is worth noting that the name of the location of the 1917 Marian apparitions has, in a sense, Muslim roots. Well, a few centuries earlier the Lusitans defeated the Moors, who sought supremacy on the Iberian Peninsula. One of the heroes of Don Gonçalo received a special privilege from King Alfonso I the Conqueror. Namely, he could choose his wife-to-be from among the captured Muslim women. The hero took advantage of this opportunity and married one of those. Her name was Fatima, and Don Gonçalo loved her very much. However, his young wife soon passed away. Don Gonçalo himself joined the Cistercians. He buried his wife next to the monastery to

${ }^{50}$ Cf. Thomas, W.A. Pope St. John Paul II \& of Fatima. An extraordinary pontificate foretold by saints, Polish translation by Meetschen, A. in: Bartosik, G.M. Kowalczyk M. (ed.), Fatima w Bożym planie zbawienia. Polskie Towarzystwo Mariologiczne. Biblioteka mariologiczna 21, Częstochowa-Zakopane 2018, 255-264.

51 John Paul II, Memory and Identity, Kraków 2005, 168.

52 Dziwisz, S. (2007) Testimony in Conversations with Gian Franco Svidercosch, Warsaw, 124. 
156 KS. PIOTR KACZMAREK • CO MARYJA MA DO POWIEDZENIA MUZUEMANOM...

ostatnie określenie. Wiadomo, że Fatima miała dwóch synów, a mimo to nazywano ją „,dziewicą”. Ponadto nazywano córkę Proroka „matką imamów" oraz przywódczynią wszystkich kobiet muzułmańskich. Islam włącza również Fatimę do tzw. „Czystej Czternastki” doskonałych ludzi (obok Muhammada i dwunastu imamów szyickich). Imię Fatimy łączone jest z symboliką otwartej dłoni, która stanowi znak błogosławieństwa Bożego i Bożej mocy ${ }^{56}$.

Wyraźny związek miejsca objawień maryjnych z imieniem córki Muhammada może być duchową wskazówką i przesłaniem dla muzułmańskiego świata. Tak widział to abp F.J. Sheen, który powiedział: „Dlaczego Najświętsza Matka w XX wieku objawiła się w mało znaczącej, niewielkiej osadzie Fatimie, dzięki czemu wszystkie przyszłe pokolenia będą Ją znały jako Matkę Bożą Fatimską. (...) sądzę, że Najświętsza Dziewica chciała być znana jako Matka Boża Fatimska na przyrzeczenie i znak nadziei dla muzułmanów oraz dla zapewnienia, że ci, którzy okazują Jej tak wiele szacunku, pewnego dnia przyjmą także Jej Boskiego Syna"57. Trudno nie odnieść tych słów do zapowiedzi, która jest często propagowana w Kościele katolickim, a mówiąca, że zwycięstwo Chrystusa przyjdzie przez Maryję. Abp F. Sheen zauważył nawet, że skoro Maryja znajduje swoje prefiguracje w Starym Testamencie, to również córka Proroka może stać się prefiguracją Maryi. I jak stwierdził ten duchowny: „Muzułmanie powinni być gotowi uznać, że jeśli Fatima musi ustąpić Najświętszej Matce pierwszeństwa w zaszczytach, to jest tak dlatego, iż jest Ona inna od wszystkich innych matek świata i że bez Chrystusa byłaby niczym" 58 .

Warto zauważyć, że w naszych czasach dostrzega się wyraźne przejawy kultu maryjnego wśród muzułmanów. Koran mówi o dwóch

${ }^{56}$ Otwarta dłoń jest symbolem błogosławieństwa i otwartości na drugiego człowieka. Szyici widzą w tym znaku symbol mocy Bożej, opatrzności i szczodrości. Pięć palców otwartej dłoni przywodzi także na myśl pięć filarów islamu. Cf. M.M. Dziekan, op. cit., 28.35.

57 F.J. Sheen, Maryja. Pierwsza miłość świata, tłum. D. Krupińska, Kraków 2018, 281.

58 Ibidem, 283. 
keep her alive this way. Later, the village of Fatima was named after her. ${ }^{53}$

The name Fatima is very common among Muslim women and refers to one of Mauhammad's daughters. Fatima (approx. in 605-633) was married to Ali Ibn Abi Talib, and the tradition has attributed to her various terms that ennoble her (Az-Zahra - Venus, As-SiddikaTruthful, Al-Batul - Virgin). This last term may be of particular interest. It is known that Fatima had two sons, and yet she was called a ,virgin'. In addition, the Prophet's daughter was called ,mother of the imams' and the leader of all Muslim women. In Islam Fatima also belongs to the so-called ,Pure Fourteen' of excellent people (alongside Muhammad and the twelve Shiite imams). Fatima's name is combined with the symbolism of an open hand, which is a sign of God's blessing and power. ${ }^{54}$

The clear link between the place of Marian apparitions and the name of Muhammad's daughter may be a spiritual guide and message to the Muslim world. This is how Archbishop Sheen sees it:

„(...) namely, why the Blessed Mother, in this twentieth century, should have revealed herself in the insignificant little village of Fatima, so that to all future generations she would be known as „Our Lady of Fatima.” (...) I believe that the Blessed Virgin chose to be known as „Our Lady of Fatima" as a pledge and a sign of hope to the Moslem people, and as an assurance that they, who show her so much respect, will one day accept her Divine Son, too." ${ }^{55}$

${ }^{53}$ Basic information related thereto in: Siccardi, C. Tajemnica Fatimy i cierpienie Kościoła, Polish translation by A. Zielińska, Kraków 2014, 61-62.

${ }^{54}$ An open hand is a symbol of blessing and openness to others. Shiites see it as a symbol of God's power, providence and generosity. The five fingers of the open hand also bring to mind the five pillars of Islam. Cf. Dziekan, M.M. op. cit., 28.35.

${ }_{55}$ Sheen, F.J. The World's First Love (2nd edition): Mary, Mother of God, McGraw-Hill Book Company, Inc. New York - London - Toronto Copyright, 1952, by Fulton J. Sheen. 
158 KS. PIOTR KACZMAREK • CO MARYJA MA DO POWIEDZENIA MUZUŁMANOM...

wymiarach współpracy z Marią, które łączą się z jej wstawiennictwem do Boga. Chodzi o fragment mówiący o Zachariaszu, który został namówiony przez Marię, by prosił Boga o cud ojcostwa w podeszłym wieku $^{59}$. Inny fragment świętej księgi islamu wspomina Marię, która została ocalona na pustyni, kiedy krańcowo wyczerpana dostrzegła strumień z życiodajną wodą ${ }^{60}$. Jak widać Bóg ma wielki wzgląd na Marię, dba o nią i słucha jej próśb. To dlatego wielu muzułmanów wierzy, że warto prosić Marię o wstawiennictwo również w swoich sprawach. O. Milad Sidky Zakhary przytacza kilka przykładów kultu maryjnego wśród wyznawców islamu ${ }^{61}$. Otóż do sanktuarium maryjnego w libańskiej Harissie przybywa wielu pielgrzymów. 50\% z nich stanowią muzułmanie. Także do wielu innych miejsc związanych z kultem Matki Bożej przybywa zauważalny odsetek wyznawców islamu (Lourdes, Algier, Efez, Fatima). W atmosferze powszechnej akceptacji zatwierdzono w Libanie uroczystość Zwiastowania jako święto państwowe (18.02.2010 r.). W Jordanii, w miejscowości Madba, otwarto meczet noszący nazwę „Meczet Chrystusa Jezusa Syna Marii" (przełom 2010/2011 r.). Natomiast w 2017 r. szejk Mohammad Ben Zayed Al Nhayyan zmienił nazwę meczetu w rejonie Abu Dhabi na „Meczet Marii Matki Jezusa” (wcześniej obiekt ten nosił jego imię).

Zapewne takich przykładów znalazłoby się więcej. Widać wyraźnie, że Maryja (Maria) łączy chrześcijan z wyznawcami islamu. Dokonuje się to w codzienności, dotyka wiary prostych ludzi, którzy w osobie Marii dostrzegają kogoś ważnego dla samego Boga, a więc i dla nich.

59 Cf. Koran 3, 37-41.

${ }^{60}$ Cf. Koran 19, 24

${ }^{61}$ Dalsze przykłady omawiam na podstawie artykułu: M.S. Zakhry, Maryja Dziewica w islamie, tłum. A. Meetschen, w: G.M. Bartosik, M. Kowalczyk (red.), op. cit., 211-212. 
It is hard not to relate these words to the announcement, which is often promoted in the Catholic Church, that the victory of Christ will come through Mary. Archbishop Sheen even noted that since Mary finds her prefiguration in the Old Testament, the daughter of the Prophet may also become a prefiguration of Mary. And as this clergyman said: ,The Moslems should be prepared to acknowledge that, if Fatima must give way in honour to the Blessed Mother, it is because she is different from all the other mothers of the world and that without Christ she would be nothing." 56

Note that in our times, there are clear manifestations of Marian devotion among Muslims. The Koran speaks of two dimensions of cooperation with Maryam, which relate to her intercession to God. The first one is a passage speaking of Zachariah, who was persuaded by Maryam to ask God for the miracle of fatherhood in old age ${ }^{57}$. The latter of the sacred book of Islam mentions Maryam, who was saved in the desert when, extremely exhausted, she saw a stream with lifegiving water ${ }^{58}$. As one can see, God has great respect for Maryam, cares for her and listens to her requests. This is why many Muslims believe that it is worth asking Maryam to intercede in their affairs as well. Father Milad Sidky Zakhary cites several examples of Marian devotion among Muslims ${ }^{59}$. Many pilgrims come to the Marian shrine in Lebanon Harissa. Of these, 50\% are Muslims. A noticeable percentage of Muslims (Lourdes, Algiers, Ephesus, Fatima) also come to many other places related to the cult of Our Lady. In the atmosphere of general acceptance, the Annunciation ceremony was approved in Lebanon as a public holiday (18.02.2010). In Jordan, in the village of Madba, a mosque was opened called „Mosque of Jesus Christ the Son of Mary" (at the turn of 2010/2011). In 2017 Sheikh Mohammad

\footnotetext{
${ }^{56}$ Ibidem, 283.

57 Cf. The Quran 3, 37-41.

58 Cf. The Quran 19, 24.

59 Further examples are discussed on the basis of the article: Zakhry, M.S. Virgin Mary in Islam, Polish translation by Meetschen, A. in: Bartosik, G.M. Kowalczyk, M. (ed.), op. cit., 211-212.
} 
160 KS. PIOTR KACZMAREK • CO MARYJA MA DO POWIEDZENIA MUZUŁMANOM...

\section{Podsumowanie}

Jak się wydaje dialog przykładu i promowania wspólnych wartości otwiera większe możliwości recepcji maryjnego orędzia, niż debata teologiczna. Doktrynalne ramy są dosyć wąskie i nie znoszą dwuznaczności. Zupełnie inny charakter ma codzienne życie wyznawców innych religii, którzy żyją obok siebie i dają sobie wzajemny przykład. Jak mogliśmy zobaczyć, Kościół nie pomija obu wymiarów dialogu. Przygląda się teologii, określa granice ortodoksji, ale nie bagatelizuje duchowych doświadczeń, które pokazują, że Maryja jest czczona na swój sposób przez wyznawców islamu.

Gdybyśmy chcieli podsumować przedstawione powyżej argumenty, można wyliczyć następujące wnioski. Dialog dogmatyczny ogranicza się do chrystologii. Chrześcijanie i muzułmanie w diametralnie różnych sposób rozumieją osobę Jezusa Chrystusa. Odrzucenie przez islam Bóstwa Jezusa zamyka dialog na etapie dogmatycznym. Dlatego należy zaakcentować perspektywę mariologiczną. Maryja w sposób doskonały realizuje cnotę posłuszeństwa, która należy do istotnych cech wiary muzułmańskiej. W ramach „pośrednictwa przykładu” warto eksponować także inne wartości, którą są na tyle uniwersalne, że mogą pociągać do naśladowania Maryi niezależnie od wyznawanej religii. Nie należy pomijać zwłaszcza postulatu o zmaganie w sprawie pokoju na świecie.

Warto ciągle badać literaturę muzułmańską i gromadzić wszelkie tradycje związane z Marią w islamie. Pomogłoby to określić zdolność percepcji teologiczno-pobożnościowej muzułmanów. Chodziłoby o budowanie takich modeli teologicznych i duszpasterskich, które brałyby pod uwagę możliwości, ale i ograniczenia mentalności oraz doświadczenia duchowego wyznawców islamu. Kościół w dialogu z islamem powinien jeszcze częściej nawiązywać do Maryi, mówić o Jej życiu duchowym i cnotach. Należy także podejmować próby oczyszczania narracji koranicznej z różnych zafałszowań wobec oryginalnej fabuły przekazanej przez Ewangelie. Oczywiście nie jest to łatwym zadaniem, z uwagi na rewerencję, jaką cieszy się Koran wśród muzułmanów. Warto zachęcać do rozwijania pobożności maryjnej, do wzywania Jej wstawiennictwa i nawiedzania sanktuariów dedykowanych Matce Bożej. Są to ważne zadania, które stoją przed Kościołem, a których podjęcie może, biorąc pod uwagę określone ramy wiary muzułmańskiej, pomóc w jeszcze szerszym dotarciu do umysłów i serc wyznawców islamu maryjnego orędzia. W ten sposób można także poszerzać recepcję tego przesłania.

Słowa klucze: dialog chrześcijańsko-muzułmański, mariologia 
Ben Zayed Al Nhayyan changed the name of the mosque in the Abu Dhabi region to ,The Mosque of Mary, Mother of Jesus'. (previously the building was named after him).

There would probably be more such examples. Hence, it is clear that Mary (Maryam) connects Christians to the followers of Islam. It happens in everyday life, touches the faith of simple people, who in the person of Mary see someone important for God himself, and therefore for them too.

\section{RECAPITULATION}

The dialogue of example and the promotion of common values seems to open up more opportunities for the reception of the Marian message than a theological debate. The doctrinal framework is quite narrow and hates ambiguity. The daily lives of the followers of other religions, who live side by side and set an example to one another, are completely different in nature. As we have seen, the Church does not overlook both dimensions of dialogue. It looks at theology, defines the boundaries of orthodoxy, but does not underestimate spiritual experiences which show that Mary is worshipped in her own way by the followers of Islam.

To recapitulate the arguments presented above, the following conclusions can be drawn. Dogmatic dialogue is limited to Christology. Christians and Muslims understand the person of Jesus Christ in diametrically different ways. Islam's rejection of the deity of Jesus closes the dialogue at the dogmatic stage. The Mariological perspective should therefore be emphasised. Mary perfectly realises the virtue of obedience, which is one of the essential features of the Muslim faith. In the framework of the ,mediation of the example', other values should also be highlighted, which are so universal that they can attract people to imitate Mary regardless of their religion. In particular, we should not overlook the call for a struggle for world peace.

It is worthwhile to research Muslim literature on an ongoing basis and to collect all traditions related to Maryam in Islam. This would 
162 KS. PIOTR KACZMAREK • CO MARYJA MA DO POWIEDZENIA MUZUŁMANOM...

\section{Nota o Autorze}

Ks. dr Piotr Kaczmarek - kapłan diecezji łowickiej. Absolwent Wyższego Seminarium Duchownego w Łowiczu. Doktorat z zakresu filozofii na Uniwersytecie Kardynała Stefana Wyszyńskiego w Warszawie. Obecnie rektor Wyższego Seminarium Duchownego w Łowiczu. Doktorant na kierunku Mariologii w Instytucie Kolbianum w Niepokalanowie, gdzie w 2019 r. uzyskał licencjat kanoniczny. Adiunkt Papieskiego Wydziału Teologicznego w Warszawie. Obszar zainteresowań: filozofia, mariologia, religiologia, teologia duchowości.

\section{Bibliografia}

Bartosik G.M., Maryja w Koranie i w Tradycji muzulmańskiej. Czy osoba Maryi może być pomostem między tymi dwiema wielkimi religiami?, „Studia Theologica Varsaviensia" 45(2007)1, 69.

Benedykt XVI, Świattość świata. Benedykt XVI w rozmowie z Peterem Seewaldem, tłum. P. Napiwodzki, Kraków 2011, 90.

Dziekan M.M., Symbolika arabsko-muzułmańska. Mały słownik, Warszawa 1997.

Fitzgerald M.L., Jan Pawet II i dialog międzyreligijny. Z katolickiego punktu widzenia, w: Jan Pawet II i dialog międzyreligijny, wybór i oprac. B.L. Sherwin, H. Kasimow, tłum. A. Nowak, Kraków 2001, 215.

II Sobór Watykański, Deklaracja o stosunku Kościoła do religii niechrześcijańskich, 3 .

II Sobór Watykański, Konstytucja dogmatyczna o Kościele, 52-69 (dalej: KK).

Jan Paweł II, Dominum et Vivificantem, 11-14.

Jan Paweł II, Redemptoris Mater, 13.

Kaczmarek P., ,,Słowa-klucze” w dialogu Kościoła Rzymsko-katolickiego z islamem po Soborze Watykańskim II, „Warszawskie Studia Teologiczne” 25(2012)1, 239-252.

Kaczmarek P., Benedykta XVI zmaganie o dialog z islamem, „Studia Theologica Varsaviensia" 50(2012)2, 245-262.

Kaczmarek P., Jan Pawet II - kontynuator czy prekursor idei dialogu z islamem - zestawienie dorobku Papieża-Polaka w kontaktach z przedstawicielami muzutmańskiego świata, „Łódzkie Studia Teologiczne” 21(2012), 107-121.

Kaczmarek P., Poróżnione dzieci Abrahama - kilka myśli na temat dialogu Kościoła katolickiego z islamem, „Studia Loviciensia” 19(2017), 125-137.

Kongregacja Nauki Wiary, Deklaracja o jedyności i powszechności zbawczej Jezusa Chrystusa i Kościoła, Watykan 6.08.2000. 
help to determine the ability of Muslims' theological and religious perception. The idea would be to build upon such theological and pastoral models that would take into account the possibilities, but also the limitations of the mentality and spiritual experience of Muslims. The Church, in dialogue with Islam, should even more often refer to Mary and speak about her spiritual life and virtues. Attempts should also be made to purge the Quranic narrative of various falsifications of the original plot passed on by the Gospels. Clearly, this is not an easy task, because the Quran is being revived by Muslims. Therefore, it is worth encouraging the development of Marian piety, inviting her to intercede and visit the shrines dedicated to Our Lady. These are important tasks that the Church faces and which, given the specific framework of the Muslim faith, can help to reach out even more to the minds and hearts of the followers of Marian address in Islam. This can also help to broaden the reception of this message.

\section{Summary}

In this article the author's intention is to attempt to give the issue of Christian-Muslim dialogue a Mariological perspective. At first it is important to show the presentation of the image of Mary in the description of Muslim theology. This serves to show how Mary is understood, where the similarities are, and where the differences are hidden. The next part of the article is an account of the Church's dialogue with the Muslim religion. Common relations between these religions have their own history, often very turbulent. However, there are also positive and gestures of kindness. The matter of dialogue gained a special place during the Second Vatican Council during which the Church sought a thread of understanding with representatives of Islam. As we observe, the main emphasis was placed on common elements. However, we cannot fail to point out the significant differences between Christianity and Islam. St. John Paul II and Benedict XVI quickly noticed that theological dialogue presents its challanges since Islam does not accept the divinity of Jesus Christ, recognizing Him only as a prophet. Such a vision is not compatible with the doctrine of the Holy Trinity and reduces the choice of Mary to the status of any ordinary person. That is why these popes proposed investing efforts in a dialogue of life, dialogue at the level of beliefs and common values 
164 KS. PIOTR KACZMAREK • CO MARYJA MA DO POWIEDZENIA MUZUŁMANOM...

Krasicki I., Watykan na rozdrożu (1960-1970), Warszawa 1971.

Majewski J., Na rozstaju - Jan Pawet II i dialog międzyreligijny, „Tygodnik Powszechny" 2834(2003)42, 11.

Melotti L., Maryja, Matka żyjących. Zarys mariologii, tłum. T. Siudy, Niepokalanów 1993, 76-82.

Prawda, Chrystus, Judaizm. Z księdzem profesorem Waldemarem Chrostowskim rozmawiają: Grzegorz Górny i Rafal Tichy, Warszawa 2018.

Przekroczyć próg nadziei. Jan Pawet II odpowiada na pytania Vittoria Messoriego, Lublin 1994.

Przybylski B., Kościół a religie niechrześcijańskie, „Ateneum Kapłańskie” 73(1969)9-10, zeszyt 2, nr 364, 292.

Rogowski R.E., Chrystologiczny sens niepokalanego poczęcia Maryi, w: J. Kumala (red.), Tota pulchra es Maria, Licheń 2004.

Sakowicz E., Doktryna islamu, w: E. Sakowicz (red.), Czy islam jest religia terrorystów?, Kraków 2002, 76-77.

Sakowicz E., Papież Benedykt XVI wobec islamu, „Studia Loviciensia” 15(2013), 123.

Stanisławski M., Ponadczasowe wezwanie do nawrócenia, pokuty i modlitwy ptynace z Doliny Pokoju w Fatimie, w: M. Stanisławski (red.), Słowa Matki. Aktualność przesłania sanktuariów Maryjnych, Bibliotheca Kolbiana. Monografie 4, Niepokalanów 2017,

Svidercoschi G.F., Sobór, który trwa. Kronika, bilans, perspektywy, tłum. L. Rodziewicz, Kraków 2003, 153-154.

Thomas W.A., Święty Jan Paweł II - papież fatimski. Nadzwyczajny pontyfikat przepowiedziany przez świętych, tłum. A. Meetschen, w: G.M. Bartosik, M. Kowalczyk (red.), Fatima w Bożym planie zbawienia. Polskie Towarzystwo Mariologiczne. Biblioteka mariologiczna 21, Częstochowa-Zakopane 2018, 255-264. von Balthasar H.U., Modlitwa i kontemplacja, tłum. Z. Włodkowa, Kraków 1965, 79. 
that are universal enough to be accepted by every man of good will who is open to transcendence.

In the last paragraph we noticed that Mariology reveals a certain opportunity for inter-religious dialogue. We can see this clearly in expounding Mary's obedience. This virtue is one of the foundations of Muslim life that calls for submission to God's will. Another aspect is the so-called „Example mediation”. Mary practiced universal values that retain their profound meaning for representatives of both religions. And finally the Fatima thread, which seems to be a sign of the times through which God spoke not only to those who venerate His Mother, but also to those who respectfully refer to Fatima, the daughter of Muhammad, whose name Mary took in some indirect way as the same of the place of the Portuguese apparitions in 1917.

Hence, an important principle is born for the Church to refer to Mary as often as possible by talking about her virtues and presenting her biblical vision when dialoguing with the Muslim religion, so as to complement the Koranic narrative. Marian piety should be encouraged and her intercession invoked, as is already the case in various shrines in the world. It is worth mentioning the part that Mary enjoys among Muslim. A Mariological rhetoric and reference to a way of living immersed in Marian spirituality could be used more frequently and to greater effect in the dialogue between the Catholic Church and Islam.

Keywords: Dialogue between the Catholic Church and Islam, Mariology

\begin{abstract}
About the Author
Fr Piotr KACZMAREK, PhD - priest of the Łowicz diocese. A graduate of the Higher Theological Seminary in Łowicz. Doctorate in philosophy at the Cardinal Stefan Wyszyński University in Warsaw. Currently the rector of the Higher Theological Seminary in Łowicz. Doctoral student in Mariology at the Kolbianum Institute in Niepokalanów, where he obtained his Bachelor of Arts in 2019. Assistant Professor at the Pontifical Faculty of Theology in Warsaw. Area of interest: philosophy, mariology, religiology, theology of spirituality.
\end{abstract}

